University of Nebraska - Lincoln

DigitalCommons@University of Nebraska - Lincoln

Faculty Publications in Food Science and Technology

1987

\title{
Food Quality and Energy Usage in Foodservice Systems: Convective Thermal Processing of Turkey Rolls
}

\author{
M. E. Matthews \\ University of Wisconsin - Madison \\ M. E. Zabik \\ University of Wisconsin - Madison \\ R. B. Maxcy \\ University of Wisconsin - Madison
}

Follow this and additional works at: https://digitalcommons.unl.edu/foodsciefacpub

Part of the Food Science Commons

Matthews, M. E.; Zabik, M. E.; and Maxcy, R. B., "Food Quality and Energy Usage in Foodservice Systems: Convective Thermal Processing of Turkey Rolls" (1987). Faculty Publications in Food Science and Technology. 74.

https://digitalcommons.unl.edu/foodsciefacpub/74

This Article is brought to you for free and open access by the Food Science and Technology Department at DigitalCommons@University of Nebraska - Lincoln. It has been accepted for inclusion in Faculty Publications in Food Science and Technology by an authorized administrator of DigitalCommons@University of Nebraska - Lincoln. 


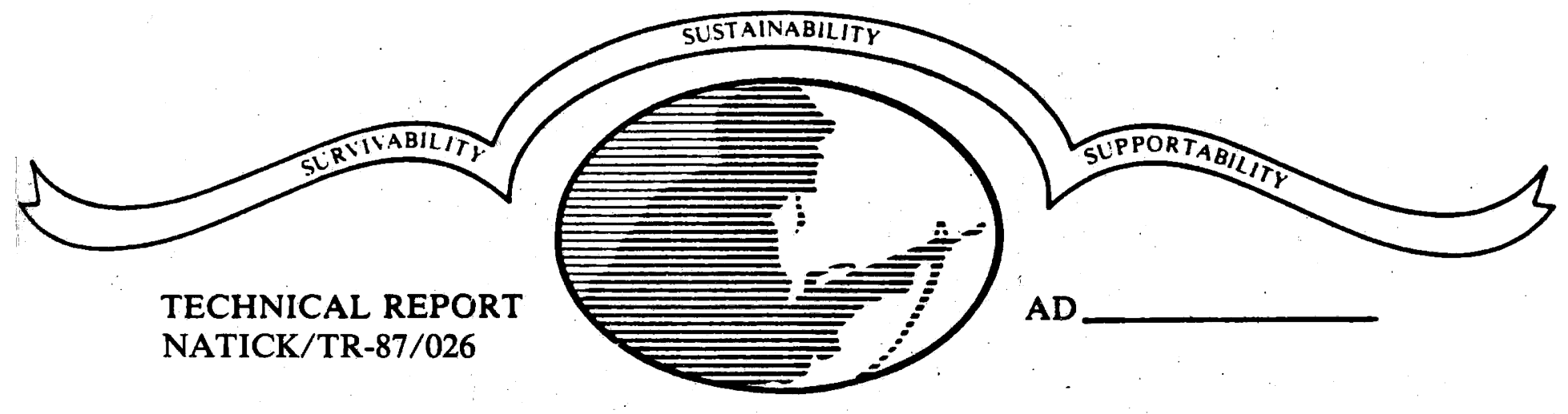

FOOD QUALITY AND ENERGY USAGE IN FOODSERVICE SYSTEMS: CONVECTIVE THERMAL PROCESSING OF TURKEY ROLLS

\author{
BY \\ M.E. MATTHEWS \\ M.E. ZABIK \\ R.B. MAXCY \\ FOOD SCIENCE DEPARTMENT \\ UNIVERSITY OF WISCONSIN - MADISON \\ MADISON, WISCONSIN 53706
}

FINAL REPORT 28 JANUARY 1987

FOR THE PERIOD MARCH 1985 TO JANUARY 1987

APPROVED FOR PUBLIC RELEASE;

DISTRIBUTION UNLIMITED

UNITED STATES ARMY NATICK

RESEARCH, DEVELOPMENT AND ENGINEERING CENTER NATICK, MASSACHUSETTS 01760-5000

SCIENCE AND ADVANCED TECHNOLOGY DIRECTORATE 


\section{Disclaimers}

The findings contained in this report are not to be construed as an official Department of the Army position unless so designated by other authorized documents.

Citation of trade names in this report does not constitute an official endorsement or approval of the use of such items.

\section{DESTRUCTION NOTICE}

For classified documents, follow the procedures in DoD $5200.1-R$, Chapter IX or DoD $5220.22-M$, "Industrial Security Manua 1," paragraph 19. For unclassified documents, destroy by any method which precludes reconstruction of the document. 


\section{REPORT DOCUMENTATION PAGE}

Ia REPORT SECURITY CLASSIFICATION

ib RESTRICTIVE MARKINGS

UNCLASS IF IED

2a SECURITY CLASSIFICATION AUTHORITY

3. DISTRIBUTION/AVAILABILITY OF REPORT

2b DECLASSIFICATION / DOWNGRADING SCHEDULE

Approved for public release; distribution unlimited.

4. PERFORMING ORGANIZATION REPORT NUMBER(S)

5. MONITORING ORGANIZATION REPORT NUMBER(S)

NATICK/TR-87/026

6a. NAME OF PERFORMING ORGANIZATION

University of Wisconsin-Madison

6b. OFFICE SYMBOL

(If applicable)

7a. NAME OF MONITORING ORGANIZATION

U.S. Army Natick RD\&E Center

Science \& Advanced Technology Directorate

Food science Department

7b. ADDRESS (City, State, and ZIP Code)

6c. ADDRESS (City, State, and ZIP Code)

1605 Linden Drive

Madison, Wisconsin 53706

Kansas St

Natick, MA 01760-5020

8a. NAME OF FUNDING/SPONSORING ORGANIZATION

8b. OFFICE SYMBOL (If applicable)

8c. ADDRESS (City, State, and ZIP Code)

9. PROCUREMENT INSTRUMENT IDENTIFICATION NUMBER

DAAK60-84-0-0089

10. SOURCE OF FUNDING NUMBERS

\begin{tabular}{|l|l|l|l}
\hline $\begin{array}{l}\text { PROGRAM } \\
\text { ELEMENT NO. }\end{array}$ & $\begin{array}{l}\text { PROJECT } \\
\text { NO. }\end{array}$ & $\begin{array}{l}\text { TASK } \\
\text { NO. }\end{array}$ & $\begin{array}{l}\text { WORK UNIT } \\
\text { ACCESSION NO }\end{array}$ \\
\hline
\end{tabular}

11. TITLE (include Security Classification)

Food Quality and Energy Usage in Foodservice Systems: Convective Thermal Processing of

Turkey Rolls

12. PERSONAL AUTHOR(S)

M.E. Matthews, M.E. Zabik, and R.B. Maxcy

\begin{tabular}{l|l|c|c|c}
\hline 13a. TYPE OF REPORT & 13b. TIME COVERED & DATE OF REPORT (Year, Month, Day) & 15. PAGE COUNT \\
Final Report & FROM Mer 85 TO Jan 87 & 1987 January 28 & 60
\end{tabular}

16. SUPPLEMENTARY NOTATION

\begin{tabular}{|c|c|c|c|c|c|}
\hline \multicolumn{3}{|c|}{ COSATI CODES } & \multicolumn{3}{|c|}{ 18. SUBJECT TERMS (Continue on reverse if necessary and identify by block number) } \\
\hline FIELD & GROUP & SUB-GROUP & FOOD SERVICE & TEMPERATURE & NUTRITION \\
\hline & & & FOOD QUALITY & CONVECTION (HEAT TRANSFER) & ENERGY \\
\hline & & & THERMAL PROCESSING & SENSORY ANALYSIS & (Continued) \\
\hline
\end{tabular}

19. ABSTRACT (Continue on reverse if necessary and identify by block number)

This study evaluated sensory and nutritional qualities, microbiological

and chemical safety of turkey rolls and enerqy use during convective thermal

processing. Turkey rolls were heat processed in home or institutional

convection ovens to an internal temperature of 77 to $80^{\circ} \mathrm{C}$ in the geometric

center of the roll. Treatment combinations included three heat-orocessing

temperatures $\left(105,135\right.$, and $165^{\circ} \mathrm{C}$ ) and two holding treatments (not chilled and

chilled for $24 \mathrm{hr}$ ) and three hot-holding times (0,60 and $120 \mathrm{~min})$.

Sensory studies of white turkey meat roasted at $165^{\circ} \mathrm{C}$ and reheated showed

that juiciness decreased significantly $(p<0.05)$, compared to roasting at 105

or $135^{\circ} \mathrm{C}$ without reheating. Juiciness was also decreased significantly

( $p<0.05)$ as hot-holding proqressed ( 0 to $120 \mathrm{~min}$ ).

\section{(Continued)}

20 DISTRIBUTION / AVAILABILITY OF ABSTRACT UUNCLASSIFIED/UNLIMITED $\square$ SAME AS RPT

22a. NAME OF RESPONSIBLE INDIVIDUAL

Durwood B. Rowley
21. ABSTRACT SECURITY CLASSIFICATION UNCLASSIFIED

22b. TELEPHONE (Include Area COde) 22C. OFFICE SYMBOL $617-651-5530$ STRNC-YM 


\section{ABSTRACT (Continued)}

Thiamin content was decreased by heat processing and, to a lesser extent, by hot-holding the turkey. Chilling meat prior to slicing and then reheating and holding did not have a detrimental effect on thiamin content.

Roasting to $77^{\circ} \mathrm{C}$ reduced the total aerobic counts from as high as 560,000 to less than 300 per $g$ and destroyed all coliforms. However, the microbial load of the uncooked product was great enough to indicate the need for care in processing for public health protection.

Polychlorinated biphenyl (PCB) analyses of commercial raw turkey white meat obtained from turkey rolls showed less than $5 \mathrm{ppb}$ of this environmental contaminant.

When two turkey rolls were heat processed at 105,135 or $165^{\circ} \mathrm{C}$, eneray consumption, on both a load and a product weight basis, was significantly (p<0.05) different between 105 and $165^{\circ} \mathrm{C}$. At $135^{\circ} \mathrm{C}$, enerqy usaqe on a watt hours/kilogram $(W h / k g)$ basis was significantly $(p<0.05)$ greater for two than for either four or six rolls. Implications of these data are that convection ovens should be operated to maximize product yield and minimize enerqy consumption.

18. SUBJECT TERMS (Continued)

MICROBIAL SAFETY

CHEMICAL SAFETY

TURKEY ROLLS 
One of the three objectives of the North Central Regional Research Project" Food Quality and Eneray Usage in Foodservice System: Microwave and Convective Thermal Processing" is to establish parameters for conserving nutritional and sensory qualities and for maintaining microbial and chemical safety of menu items. Numerous criteria were established for product selection. These included: substantial source of protein, uniform product, requires thermal processing, large volume as used in the foodservice industry, reasonable cost, reliable suppliers, widely accepted and is of importance now and expected to be of importance into the 21 st century. Turkey rolls were chosen as the first product to be used in the investiqation under contract with the Department of the Army, U.S. Army Natick Research, Development and Engineering Center, Natick, MA.

The results of using forced-air convection ovens operating at 105, 135, and $165^{\circ} \mathrm{C}$ to roast turkey rolls to $77^{\circ} \mathrm{C}-80^{\circ} \mathrm{C}$ showed that sensory qualities and nutrient retention varied sliahtly. Holdina sliced turkey from 0 to 120 minutes also resulted in slightly lower average thiamin retention; however, the small differences in the data negate the significance of the statistical findings.

Roasting to an internal temperature of $77^{\circ} \mathrm{C}-82^{\circ} \mathrm{C}$ eliminated all coliforms, an indicator of public health significance. PCBs were not detected. Yield, roasting time, and energy usaqe were significantly affected by oven temperature. Energy usage was also affected by oven load. This information contributes to a second objective which is to determine eneray expenditure for different thermal processing parameters. 
The final objective is to develop a data base on food quality and enerqy expenditures for use in decision making models for effective foodservice management. Data from this research project provide a basis for foodservice administrators to balance oven availability, product need, product auality, and energy usage. Further development of the data base with information from other food products will increase the body of knowledge available about foodservice technology.

Results of this study will be useful to managers in all seaments of the foodservice industry. Additional studies need to be done, using data generated by this project based on actual time and temperature relationships, to develop models that can predict quality and energy usage of the food product. Collaborative studies of quality and safety characteristics as well as energy use under comparable time and temperature relationships should be continued. Other menu items (e.q. fish products) and other classes of foods (e.g. vegetables) need investigation. 
This project was completed under contract (DAAK60-84-C-0089) with the Department of the Army, U.S. Army Natick Research, Development and Engineerina Center, Natick, MA., supplier of the turkey rolls. The work was directed by the North Central (NC-120) Reqional Research Committee of the United States Department of Agriculture. The research was administered through the Agricultural Experiment Station system in nine states as follows:

\begin{tabular}{|c|c|c|}
\hline State & Area of specialization & Project Leader \\
\hline Illinois & Nutritional Quality & $\begin{array}{l}\text { Dr. B.P. Klein } \\
\text { Univ. of Illinois }\end{array}$ \\
\hline Iowa & $\begin{array}{l}\text { Energy Usage } \\
\text { Sensory Evaluation } \\
\text { Nutritional Quality }\end{array}$ & $\begin{array}{l}\text { Dr. N. E. Brown } \\
\text { Iowa State Univ. }\end{array}$ \\
\hline Kansas & $\begin{array}{l}\text { Sensory Quality } \\
\text { Nutritional Quality }\end{array}$ & $\begin{array}{l}\text { Dr. C.S. Setser } \\
\text { Kansas State Univ. }\end{array}$ \\
\hline Michigan & Chemical Safety & $\begin{array}{l}\text { Dr. M.E. Zabik } \\
\text { Michiqan State Univ. }\end{array}$ \\
\hline Minnesota & Microbiological Quality & $\begin{array}{l}\text { Dr. E.A. Davis } \\
\text { Univ. of Minnesota }\end{array}$ \\
\hline Missouri & Energy Usage & $\begin{array}{l}\text { Or. N.F. Unklesbay } \\
\text { Univ. of Missouri }\end{array}$ \\
\hline Nebraska & Fundamental Microbiology & $\begin{array}{l}\text { Dr. R.B. Maxcy } \\
\text { Univ. of Nebraska }\end{array}$ \\
\hline Ohio & Sensory Quality & $\begin{array}{l}\text { Dr. M.L. Cremer } \\
\text { Ohio State Univ. }\end{array}$ \\
\hline Wisconsin & $\begin{array}{l}\text { Energy Usage } \\
\text { Microbiological Quality } \\
\text { Nutritional Quality }\end{array}$ & $\begin{array}{l}\text { Dr. M. E. Matthews } \\
\text { Univ. of Wisconsin- } \\
\text { Madison }\end{array}$ \\
\hline
\end{tabular}


The researchers wish to acknowledqe the cooperation, interaction and technical expertise of Dr. D. B. Rowley, Chief of the Biological Sciences Division, Science and Advanced Technology Directorate, U.S. Army Natick Research, Development, and Engineering Center, Natick, MA.

Special appreciation is extended to the following members of the NC-120 Regional Research Committee for their leadership role in the research and the writing of sections of this report.

Section

Food Preparation Procedures and Measurements for Turkey Rolls

Sensory Quality

Nutritional Quality

Microbiological Safety

Chemical Safety

Energy Usage
Researcher

$$
\begin{aligned}
& \text { Or. N.E. Brown } \\
& \text { Iowa State University and } \\
& \text { Dr. C.S. Setser } \\
& \text { Kansas State University } \\
& \text { Or. C.S. Setser } \\
& \text { Kansas State University } \\
& \text { Or. B.P. Klein } \\
& \text { University of } 111 \text { inois } \\
& \text { Or. R.B. Maxcy } \\
& \text { University of Nebraska } \\
& \text { Or. M.E. Zabik } \\
& \text { Michigan State University } \\
& \text { Dr. N.F. Unk lesbay } \\
& \text { University of Missouri-Columbia }
\end{aligned}
$$

Other contributors to this project were Dr. J. Love, who supervised the nutritional analysis of turkey rolls at lowa State University, Dr. J.A. Milner from the 11 inois Agriculture Experiment Station who is the Administrative Advisor to NC-120, and Dr. R. Garner from the U.S. Department of Aariculture who is the USDA Advisor to $N C-120$. We also acknowledqe G.N. Bookwalter, from the USDA Northern Reqional Research Center in Peoria, Illinois who is a liaison representative to $\mathrm{NC}-120$, for $\mathrm{his}$ helpful comments on the final draft of this manuscript. 
PREFACE

V

LIST OF ILLUSTRATIONS viii

LIST OF TABLES

INTRODUCTION

METHODS AND MATERIALS

Experimental Design 5

Description of Product 5

Preparation for Thermal Processing 6

Quality Measures $\quad 7$

Sensory Analyses

Nutritional Analyses

Microbiological Analyses $\quad 10$

Chemical Analyses $\quad 11$

Energy Usage $\quad 14$

RESULTS AND DISCUSSION 16

Time and Temperature Data 16

Product Yield 19

Sensory Studies $\quad 22$

Nutritional Studies $\quad 32$

Microbiological Safety 36

Chemical Safety 38

$\begin{array}{ll}\text { Energy Use } & 39\end{array}$

CONCLUSIONS AND RECOMMENDATIONS 46

REFERENCES

PUBLICATIONS FROM THE PROJECT 53 


\section{LIST OF ILLUSTRATIONS}

Figures

Page

1. Score Card for Sensory Analys is of Turkey Roasts

2. Comparison of Gas Liquid Chromatograph (GLC) Tracinq of PCB Standard with that of Turkey Roll Samples.

3. Representative Heating Curves for One Turkey Roast Cooked in a Home Convection Oven (above) and Two Turkey Roasts Cooked in an Institutional Convection Oven (below).

4. Time Needed to Reach Predetermined Oven Temperatures and Total Cooking Times for All Turkey Rolls to Reach $77^{\circ} \mathrm{C}$ or above in a Convection Oven When Usina Three Oven Loads and Three Oven Temperatures.

5. Mean Scores for Juiciness in Turkey Roasts Cooked at Three Oven Temperatures, with and without Chilling and Reheatinq.

6. Mean Scores for Roasted Aroma in Turkey Roasts Cooked at Three Oven Temperatures, with and without Chilling and Reheating.

7. Mean Scores for Meaty, Cooked Flavor in Turkey Roasts Cooked at Three Oven Temperatures, with and without Chilling and Reheating.

8. Mean Scores for Off-Notes in Turkey Roasts Cooked at Three Oven Temperatures, with and without Chilling and Reheating.

9. Mean Scores for Texture in Turkey Roasts Cooked at Three Oven Temperatures, with and without Chilling and Reheating.

10. Mean Scores Pooled for All Treatment Combinations for Juiciness of Turkey Roasts After Hot-Holding 0,60, and 120 min at $105^{\circ} \mathrm{C}$.

11. Mean Scores Pooled for All Treatment Combinations for Sensory Flavor Attributes of Turkey Roasts After Hot-Holding 0,60 , and $120 \mathrm{~min}$ at $105^{\circ} \mathrm{C}$.

12. Mean Scores Pooled for All Treatment Combinations for Crumbly, Mealy Texture of Turkey Roasts After Hot-Holdina 0,60 , and $120 \mathrm{~min}$ at $105^{\circ} \mathrm{C}$.

13. Thiamin Content of White Turkey Meat at Illinois.

14. Percentage Thiamin Retention in White Turkey Meat at Illinois. 
Tables

Page

1. Forecasts for Foodservice Sales During 1986 by Market Segment.

2. Quality Factors Studied and States with Major Responsibility for Procedures.

3. Heating Times for Turkey Roasts Prepared in Home Convection Ovens.

4. Heat Processing Parameters for Turkey Roasts.

5. Mean Weights of Turkey Roasts Before and After Heating, and the Percentage of Yield in a Convection Oven at Three Oven Loads and Three Oven Temperatures at Wisconsin.

6. Least Square Means Showing Treatment Effects on Sensory Parameters of Turkey Rolls.

7. Least Square Means Showing Holding Time Effects on Sensory Parameters of Turkey Roasts.

8. Experimental Error Variances of Sensory Data.

9. Thiamin Content (mcq/100q) of Cooked White Turkey Meat.

10. Microbial Evaluation of Surface and Core Samples of Raw Turkey Rolls at Minnesota and Nebraska.

11. Microbial Evaluation of Surface Samples of Raw Turkey Rolls at Wisconsin.

12. The Effect of Cooking to $77^{\circ} \mathrm{C}$ and Subsequent Hot-Holding on the Total Microflora of Turkey Roasts at Wisconsin.

13. Heat Processing Parameters and Energy Consumption for Turkey Roasts at Iowa and Missouri.

14. Energy Usage for Heat Processing Three Oven Load Sizes of Turkey Roasts.

15. Energy Usage for Heat Processing Turkey Roasts at Wisconsin. 

FOOD QUALITY AND ENERGY USAGE IN FOODSERVICE SYSTEMS:

CONVECTIVE THERMAL PROCESSING OF TURKEY ROLLS

INTRODUCTION

Forecasts for foodservice sales during 1986 show differences of opinion among estimates by Restaurants and Institutions Maqazine, the National Restaurant Association, and Technomic Consultants. These differences are partially related to methods of data accumulation and to assumptions about inflation (Table 1). However, all three agree on a conservative rate of real growth for the military segment (1).

The foodservice industry consists of individual market seqments that have specialized requirements for food, equipment and supplies and use unique methods of purchasing, storing, preparing and serving meals and snacks to meet the needs of customers. Therefore, expansion or shifts in trends within market segments will probably have implications for the numerous businesses (food, equipment, supplies, and services) that sell goods and services to the foodservice industry (2).

Changes in consumer attitudes and lifestyles will continue to affect many of the foodservice industry segments in the future. Consumers are likely to continue to be interested in health and nutrition with a concomitant taste for healthful menu items such as poultry, salads, and vegetables (3). When making decisions about menu items, administrators in military, commercial, and institutional foodservices consider food quality and cost. Quality food is selected, prepared, and served so that the food is microbiologically and chemically safe, retains or enhances sensory properties, conserves nutrients, and is sought by consumers. Food auality is probably affected more by thermal processing than any other step in food preparation. The primary focus of this 
TABLE 1. Forecasts for Foodservice Sales During 1986 by Market Seqment. ${ }^{a}$

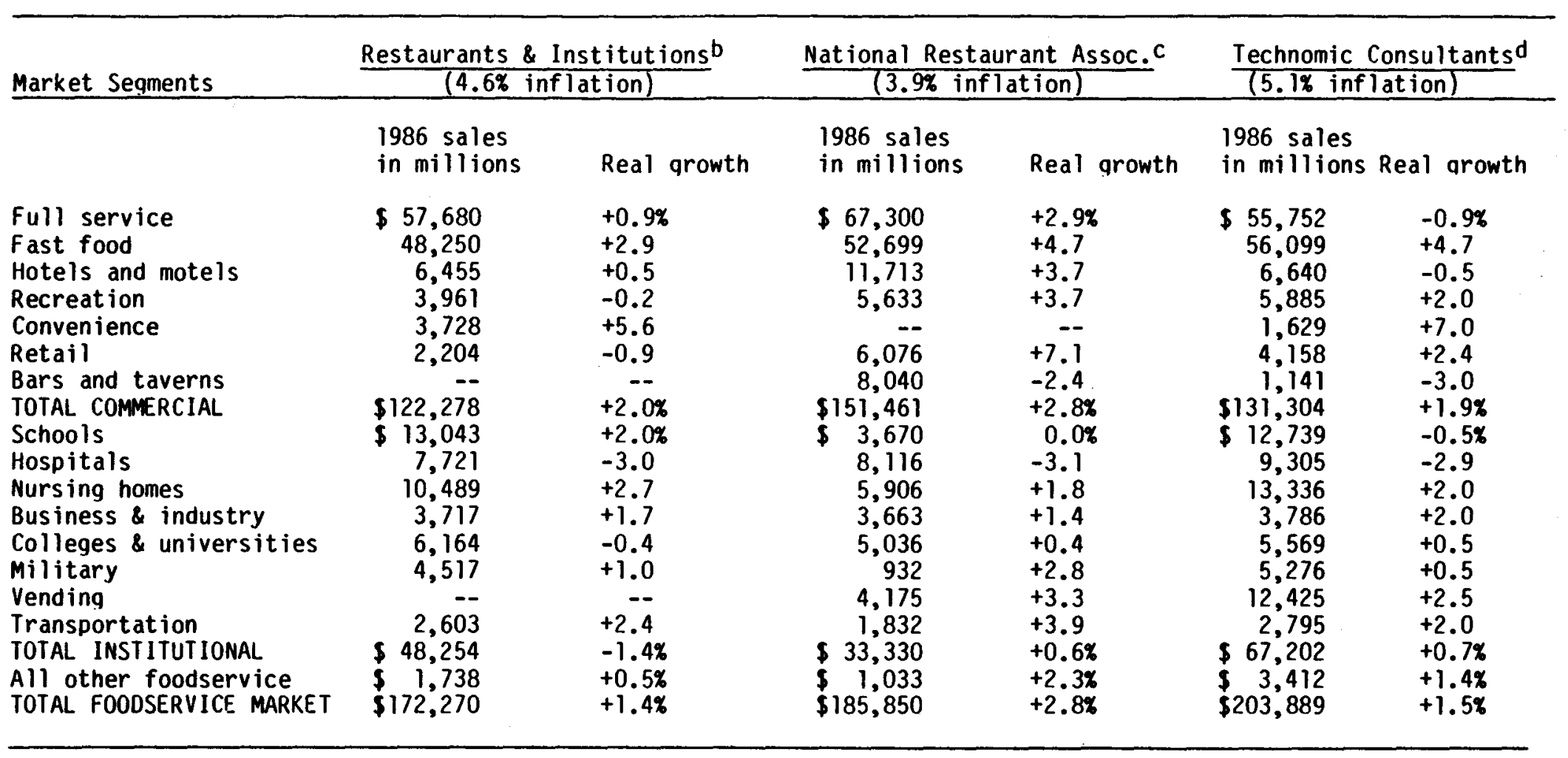

a Adapted from Restaurants \& Institutions, 1986(1).

b No alcoholic beveraqe sales are included. Commercial cafeterias are included in full-service. Convenience includes grocery. Vending sales are included in the market seqment where they occur. In all institutional (captive) seqments, fiqures are calculated as commercial-sales equivalents, based on food purchases. Food contractor sales are included in the seament where they occur. Separate drinking place food sales are included in full service. "Other" includes primarily social clubs, prisons and recreation cambs.

c NRA includes alcoholic beveraqe sales in all fiqures. In the institutional (captive) seaments, actual dollars spent are reported. Commercial equivalents are calculated for nursing homes. Sales for food contractors are added here to the segment where the sale occurs. Vendina fiqures include only food and beverages. Commercial cafeterias and social caterers are included in full service. Mobile cafeterias and community centers are included in "other" foodservice. Military figures are for the continental United States only. Convenience store food sales are part of retail.

d Transportation fiqures are from airlines only. Alcoholic beveraqe sales are not included in any market seament. In all institutional (captive) seqments, fiqures are calculated as equivalent commerical sales, based on food purchases. Vending sales include all food and beveraqes. Separate drinkina place sales (food only) are included in full service. "0ther" includes prisons, convents, clubs, railroads, ships and miscellaneous seaments. Total institutional includes other captive. Grocery stores are included in retail. 
two-year component of a five-year project was convective thermal processina, because convection ovens are widely used throughout the foodservice industry.

There were three primary objectives for this project (1984-1986):

1. Establish parameters for conserving nutritional and sensory qualities of a menu item, while maintaining microbial and chemical safety.

2. Determine energy expenditures for different thermal processing parameters used in preparing a selected menu item in forced-air convection ovens.

3. Develop a data base on food auality and eneray expenditures for a selected menu item for use in decision makina models for effective foodservice manaqement.

Experimentation was limited to convective thermal processing for foodservice systems. A menu item was selected that met the following criteria, established by the North Central-120 Regional Research Committee:

1. Product contains one or more critical nutrients; at least one product shall have substantial protein content.

2. Product is fairly uniform in product composition.

3. Product is appropriate to convective thermal processing.

4. Product is used in large volume by the foodservice industry.

5. Product is of reasonable cost.

6. Product has reliable supplier.

7. Product is widely accepted within the qeneral population.

8. Product is of importance now and is expected to be of importance into the 21 st century. 
The menu item selected as meeting these criteria was turkey rolls (frozen). Consumption of turkey meat in both the retail and commercial markets has been increasing over the last 25 years (4). The turkey rolls, formulated according to commonly accepted specifications and available from a dependable source, were provided by the U.S. Army Natick Research and Development Center through contract (DAAK60-84-C-0089). Turkey rolls were from a single lot; thus individual rolls constituted a random sample.

The research work was completed in three phases to maximize the effectiveness of joint efforts among the universities and to take advantage of the combined expertise in food quality and enerqy usage methods for foodservice research. The type of research, quality factors studied, and research sites with major responsibility for procedures are shown in Table 2 .

TABLE 2. Quality Factors Studied and States with Major Responsibility for Procedures

\begin{tabular}{llllll}
\hline $\begin{array}{l}\text { Type of } \\
\text { research }\end{array}$ & $\begin{array}{l}\text { Sensory } \\
\text { quality }\end{array}$ & $\begin{array}{l}\text { Nutritional } \\
\text { quality }\end{array}$ & $\begin{array}{l}\text { Microbioloqical } \\
\text { safety }\end{array}$ & $\begin{array}{l}\text { Chemical } \\
\text { Safety }\end{array}$ & $\begin{array}{c}\text { Enerqy } \\
\text { use }\end{array}$ \\
\hline $\begin{array}{l}\text { Standardization } \\
\text { of methods }\end{array}$ & Kansas & Illinois & Nebraska & Michiaan & Missouri \\
$\begin{array}{l}\text { Validation of } \\
\text { methods and } \\
\text { findings }\end{array}$ & Illinois & $\begin{array}{l}\text { Kansas } \\
\text { Wisconsin }\end{array}$ & Minnesota & Michigan & Iowa \\
$\begin{array}{l}\text { Application to Iowa } \\
\text { foodservice }\end{array}$ & $\begin{array}{l}\text { Iowa } \\
\text { Wisconsin }\end{array}$ & $\begin{array}{l}\text { Nebraska } \\
\text { Wisconsin }\end{array}$ & Michigan & Iowa \\
\end{tabular}

The product to be used, variables to be studied, and procedures for the study were predefined, validated, and followed by the researchers contributina to the project. 


\section{METHODS AND MATERIALS}

EXPERIMENTAL DESIGN

Most phases of this experiment involved with six treatment combinations. The treatment combinations included three cooking temperatures $(105,135$, and $165^{\circ} \mathrm{C}$ ) and two holding treatments (not chilled and chilled for $24 \mathrm{hr}$ ). Turkey rolls from each treatment combination were subjected to three hot-holding times $(0,60$, and $120 \mathrm{~min})$. Zero time for hot-holdina was reached when half of the thermocouples indicated that the internal temperature of turkey slices had reached 66 to $67^{\circ} \mathrm{C}$ or above. Thereafter, slices were held for 60 or 120 min. Turkey rolls were cooked at the selected temperature, then sliced and held for the three hot-holdina times or chilled for $24 \mathrm{hr}$ before slicina, reheating, and holding. The combinations of cooking time and holding treatment were selected randomly and specified for each day of the study.

\section{DESCRIPTION OF PRODUCT}

The frozen, raw, boneless, ready-to-cook turkey rolls were formulated in accordance with USOA specifications which were: breast meat (minimum $47.0 \%$ of total), thigh meat (maximum $34.0 \%$ ), skin (maximum 12.5\%), water (5.0\%), iodized salt (1.0\%), and sodium phosphates $(0.5 \%)$. Breast meat could replace thigh meat, and either breast meat or thigh meat could replace skin. The maximum percentage of thigh meat could be exceeded if thigh meat replaced skin and the minimum percentage of breast meat was obtained. A minimum of $75 \%$ of the outer surface was to be covered by skin. The finished product requirements for the turkey rolls allowed for variations in lenath (23 to 43 $\mathrm{cm})$, diameter $(10$ to $18 \mathrm{~cm})$, and weight $(3.6 \mathrm{~kg}$ to $5.4 \mathrm{ka})$. Norbest Incorporated, Salt Lake City, Utah was the supplier of the turkey rolls to the U.S. Army Natick Research and Development Center. These rolls were netted and 
placed in sealed moisture-proof casings, frozen and shipped to arrive at each research site between October 1984 and January 1985.

PREPARATION FOR THERMAL PROCESSING

Turkey rolls were held in frozen storaqe, at approximately $-20^{\circ} \mathrm{C}$. Prior to roasting, rolls were thawed at $4^{\circ} \mathrm{C}$ for 48 to $72 \mathrm{hr}$ to an internal temperature of 0 to $6^{\circ} \mathrm{C}$ in the qeometric center of the roll. The moistureproof bag was removed from the thawed turkey roll just prior to cooking, while the net was left in place.

Turkey rolls used for sensory and microbiological studies were roasted within 4 to 8 months after receiving the products. Nutritional, chemical, and energy studies were completed within approximately 9 months.

Two sizes of forced convection ovens (household and institutional) were used to evaluate extremes in oven sizes as might be used in military foodservice. The household oven was a Farberware Convection turbo-oven (Model 460/5). Turkey rolls were cooked, uncovered, to an internal temperature of $80^{\circ} \mathrm{C}$ in the geometric center of the roll (Illinois and Kansas). The electric institutional convection ovens used included: Zephaire Model EF-111, the G.S. Blodgett Company Inc. and Lanq Model ECCO-6, the Lanq Manufacturing Company. Turkey rolls were also placed in the center of the oven, uncovered (Missouri and Wisconsin) or covered with aluminum foil (Iowa and Ohio) and cooked to an internal temperature of $77^{\circ} \mathrm{C}$ in the geometric center of the roll.

Time-temperature data were collected at the qeometric center of the turkey roll by using recording potentiometers. Oven roasting temperature and internal meat temperature were recorded every 4 to 5 min throughout roastina and 15 to 30 min after roasting. Total cooking losses, drip and evaporative losses were based on cooked weights taken 15 min after the turkey rolls were removed from the oven. After standing for $15 \mathrm{~min}$, the turkey roasts were 
either placed in a refrigerator at $4^{\circ} \mathrm{C}$ to chill overnight (Illinois, Iowa, Kansas and Ohio) or sliced into $1-\mathrm{cm}$ slices (Illinois, Iowa, Kansas, Ohio and Wisconsin) for hot-holding. Slices for the 0 holding time were evaluated within 30 min of removal of the turkey roasts from the ovens. Temperature of the holding equipment was monitored and adjusted to maintain the internal temperatures of the turkey slices at 66 to $67^{\circ} \mathrm{C}$.

Only white meat was sampled for quality evaluations so slices with maximum amounts of white meat were selected for holding. Turkey meat was held at $66^{\circ} \mathrm{C}$ in the geometric center for either 60 or $120 \mathrm{~min}$. Four slices (about 495 to $500 \mathrm{~g}$ per pan) were held in covered disposable half-sized steam table pans or turkey slices were stacked in pans (approximately 800-q Der pan). Various types of hot-holding equipment were used, but all equipment was calibrated so that the temperature in the qeometric center of the meat when reheated was $66^{\circ} \mathrm{C}$

Chilled meat was removed from the refriqerator after $24 \mathrm{hr}$, sliced as described previously, and reheated at $105^{\circ} \mathrm{C}$ to an internal temperature of $66^{\circ} \mathrm{C}$ for the 0 holding time. Samples were then treated in the same manner as the turkey meat that was not chilled. Statistical tests, as appropriate for each parameter being studied, were done accordina to commonly accepted procedures for analyses.

QUALITY MEASURES

Sensory Analyses

Sensory analyses of turkey meat were conducted at four Aqricultural Experiment Stations: Illinois, lowa, Kansas, and Ohio.

Panelists. Faculty, staff, and students at the various universities were trained during a two-week period ( $3 \mathrm{hr}$ per week) to do the sensory analyses of the samples of turkey meat. Seven to twelve panel members were trained. From 
pools of twelve panelists, four to six panelists were selected randomly at Kansas and Illinois, respectively, and assigned to sampling periods for every treatment and time. The same panelists were used at each taste panel session at Lowa and Ohio.

Training consisted of introducing panelists to the score card and definina terminology used in this study. Panel members were given samples and trained to recognize characteristics of the extremes, or anchors, for each attribute to be evaluated. The score card used in this study is illustrated in Fiqure 1.

Preparation of samples. Two or four 1-cm-thick slices of turkey from each holding period were used for sensory analyses. A 1.3-cm-diameter corer was used to cut sample cores for each panelist to determine chew count. Approximately 2 to $3-\mathrm{cm}$-diameter samples were used for evaluating other sensory attributes of the turkey.

Holding and serving of samples. Turkey cores were placed in prewarmed 50 to $150-\mathrm{mL}$ glass beakers covered with watch glasses. Each sample had its own holding beaker. These covered beakers were placed in a pan of hot water maintained at approximately $62^{\circ} \mathrm{C}$ on an electric warming tray set at $93^{\circ} \mathrm{C}$.

Panelists served themselves at the designated hour of testina by selectina two cores from each beaker. Reference samples for aroma, representing partially roasted and extensively-roasted turkey to develop browned aromatics, were provided for the evaluators at Illinois and Kansas. These samples were held at room temperature in covered qlass brandy snifters and retained their characteristic aromas.

\section{Nutritional Analyses}

of the nutrients in poultry, thiamin is the most labile and, therefore, it was used as an indicator of nutritional quality because its destruction would 


\section{INTENSITY RATINGS: TURKEY ROASTS \\ LIGHT MUSCLE}

Name

Date

Place a vertical line across the horizontal line at the point representing your perception of the characteristic's intensity. Re-testing is permitted.

AROMA

\begin{tabular}{ll}
\hline Partialiy cooked & Roasted
\end{tabular}

JUICY MOUTHFEEL

$\overline{\text { Very dry }}$ Very juicy

\section{TEXTURE}

Fibrous, stringy

Chew Count

FLAVOR: MEATY, COOKED TURKEY

None

Intense

FLAVOR : OFF-NOTES

None

Strong,gtale

Thank you!

Figure 1. Score Card for Sensory Analys is of Turkey Roasts 
be most likely to occur under adverse heat processina conditions. Although poultry is not an excellent source of thiamin, it provides about 40 to 60 $\mathrm{mcg} / 100 \mathrm{~g}$ meat.

Thiamin content and retention were determined from turkey roasted in household size forced-air convection ovens (Illinois and Kansas) and institutional forced-air convection ovens (Iowa and Wisconsin). After roasting at 105,135 , and $165^{\circ} \mathrm{C}$, chilling $24 \mathrm{hr}$ at $4^{\circ} \mathrm{C}$ or not chilling and holding slices at approximately $66^{\circ} \mathrm{C}$ for 0,60 , or $120 \mathrm{~min}$, approximately 50 a of the sliced white meat was removed for nutritional analysis. These samples were held frozen at $-20^{\circ} \mathrm{C}$ until analyzed for thiamin using a modification of the thiochrome assay method (5). Thiamin was expressed as mca/100 a on a wet-weight basis, using the AOAC method 24.003 (6).

\section{Microbiological Analyses}

Sampling and Evaluation of Raw Turkey Rolls. Following thawing, for each analysis an $11-g$ sample was removed aseptically by random selection from various areas of the surface of a turkey roll. To determine internal microbial contamination, a $2.54-\mathrm{cm}$ core was taken aseptically from the midsection of a roll and an 11-q sample was removed from the middle of the cored portion. Each sample was then blended with $99 \mathrm{~mL}$ of phosphate buffer for subsequent decimal dilutions and platings in duplicate with plate count agar (PCA) and violet red bile agar (VRBA). Plate count aqar was used to determine total aerobic plate count and VRBA was chosen to determine coliforms, indicators of microorganisms of public health siqnificance. Plates were incubated at $32^{\circ} \mathrm{C}$ at Nebraska, $35^{\circ} \mathrm{C}$ at Wisconsin, and $37^{\circ} \mathrm{C}$ at Minnesota. The high temperature selected by Minnesota was chosen to correspond with standard medical procedures for evaluating pathogens in products. Incubation 
times for VRBA ranged from 18 to $24 \mathrm{hr}$ with the shortest time associated with the highest temperature. Incubation time for PCA was $48 \mathrm{hr}$.

Sampling and Evaluation of Cooked Turkey Roasts. After cooking as described previously, turkey roasts were sliced into 1.0 to $1.2-\mathrm{cm}$ pieces. Eleven-gram samples were taken aseptically from the approximate center of slices by Nebraska and Minnesota, while Wisconsin obtained samples from various areas on the surface of turkey roasts. Surface samples were also obtained by wisconsin after hot-holding at 0,60 , and $120 \mathrm{~min}$. Samples were blended and subsequent decimal dilutions were made. Platings were in duplicate on PCA and VRBA and incubated at 32 to $37^{\circ} \mathrm{C}$ for 48 and $24 \mathrm{hr}$, respectively. These procedures were in general accord with the methods out lined by Speck (7).

\section{Chemical Analyses}

PCB Analyses. Representative samples of turkey rolls in excess of $100 \mathrm{q}$ were obtained from four states receiving turkey rolls from the common lot of turkey rolls supplied by the Department of the Army under this contract (Contract No. DAAK60-84-C-0089). In each of these states, the turkey rolls were sliced frozen using a band saw, and frozen samples were wrapped in foil and then placed in sealed polyethylene bags, packed in dry ice, and shipped by air to the Michigan Agricultural Experiment Station. All samples were received frozen. After receipt, the samples were thawed and the white meat separated. The white meat was pulverized in an Osterizer blender before duplicate 10-g samples were taken for polychlorinated biphenyl (PCB) analyses. PCBS were analyzed by hexaneacetone extractions, acetonitrile partitioning and Florisil-celite column cleanup according to the method of Yadrick et al. (8). An aliquot of the hexane was dried under vacuum at $70^{\circ} \mathrm{C}$ to estimate fat. Following the final concentration, PCBs were quantitated by 
capillary column gas chromatographic analysis using a Tracor 560 qas

chromatograph (GLC) equipped with a ${ }^{63} \mathrm{Ni}$ electron capture detector and interfaced with a Spectra-Physics chromatograph integrator, model SP 4270. The capillary column for the GLC was a $0.25-\mathrm{mm} \times 30-\mathrm{m}$ fused silica column with a 0.25-micron DB-1 stationary phase. Column pressure was $138 \mathrm{kPa}$. The initial oven temperature was $170^{\circ} \mathrm{C}$ and was programmed to rise at $4^{\circ} \mathrm{C} / \mathrm{min}$ until it reached $270^{\circ} \mathrm{C}$. Final holding time at $270^{\circ} \mathrm{C}$ was $10 \mathrm{~min}$. The injector and detector temperatures were 250 and $300^{\circ} \mathrm{C}$, respectively. Standards were prepared with Aroclor 1254 in nanograde hexane.

Quantitations were based on the area of the PCB peaks 3.22 to 24.30 of the Aroclor standard as illustrated in Figure 2. Standards were run at the beginning of each day and after every six samples. PCBs were expressed on an edible tissue, solid and fat basis. Recoveries of Aroclor 1254 from samples spiked with $50 \mathrm{ppb}$ to $5 \mathrm{ppm} 1254$ were $98 \%+1 \%$. Limit of detection was $5 \mathrm{ppb}$. 


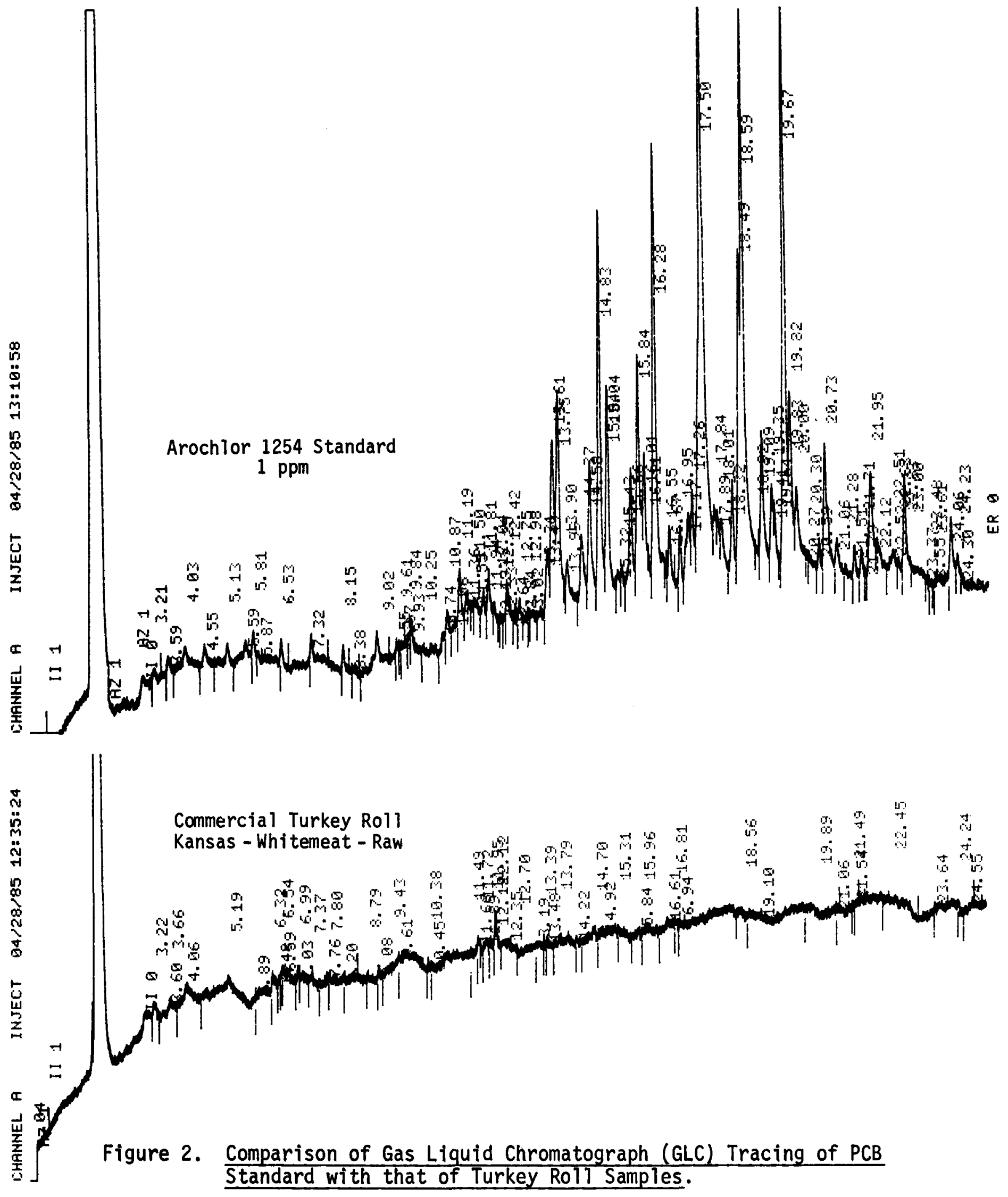




\section{Energy Usage}

Electrical energy usage was monitored durinq three staqes: convective thermal processing of the turkey roll (Iowa, Missouri, and Wisconsin), convective heating of chilled slices of turkey roll (Iowa), and convective hot-holding of the turkey slices (Iowa and Wisconsin). Procedures as described in the previous section were followed. A diqital eneray monitor (DuPont, Model EMT-KWO; DuPont Energy Management, Dallas, TX) was used to record energy consumed by the convection oven. Enerqy consumption in watt hours was recorded after the oven doors were closed and the oven was turned on until the internal product temperature of all the turkey rolls had reached $77^{\circ} \mathrm{C}$. Energy usage was expressed as watthours/load (Wh/load) and watthours $/ \mathrm{kg}(\mathrm{Wh} / \mathrm{kg})$ of raw turkey rolls, for the thermal processing of the turkey rolls.

Scientists at Iowa and Missouri used an identical model of a forced-air convection oven and identical procedures. Their research design with this oven first involved heat processing with an oven load size of two turkey rolls at each of the three temperatures $\left(105,135\right.$, and $\left.165^{\circ} \mathrm{C}\right)$. These data were pooled since conditions were identical in both Agricultural Experiment Stations. Additional data were collected with oven loads of 4 and 6 rolls at the oven temperature of $135^{\circ} \mathrm{C}$. Again, because of similar conditions, data were pooled and statistically analyzed.

Scientists at wisconsin used a different model of forced-air convection oven. The research approach used was to obtain enerqy data for each of the nine treatments, i.e., three different oven temperatures and three different oven load sizes. This coordinated approach presented information about eneray consumption for each of these nine treatments. 
Oven placement at all three Agricultural Experiment Stations was:

2 rolls -- Pans were placed adjacent to each other on one rack located in the center of the oven.

4 rolls -- Pans were placed adjacent to each other on two racks which were centered in the oven cavity.

6 rolls -- Pans were placed adjacent to each other on three racks which were centered in the oven cavity.

For the Lang convection ovens at Iowa and Missouri, the rack with two rolls was located $21.2 \mathrm{~cm}$ from the bottom of the oven. When four rolls were used, two rolls were placed 31.2 and $16 \mathrm{~cm}$ from the bottom of the oven, respectively. When six rolls were studied, two rolls were placed $36.1,21.2$, and $5.8 \mathrm{~cm}$ from the bottom, respectively. For the Blodqett convection oven at Wisconsin, the rack with two rolls was located $15.9 \mathrm{~cm}$ from the bottom of the oven; those for four rolls, $15.9 \mathrm{~cm}$ and $1.9 \mathrm{~cm}$ from the bottom of the oven; and those for six rolls, $29.8 \mathrm{~cm}, 15.9 \mathrm{~cm}$, and $1.9 \mathrm{~cm}$ from the bottom.

For chilled slices at lowa, the oven temperature was proqrammed for $105^{\circ} \mathrm{C}$ to heat the turkey slices to $60^{\circ} \mathrm{C}$ then the oven was reprogrammed for $66^{\circ} \mathrm{C}$ to maintain internal temperature of the slices at $66^{\circ} \mathrm{C}$. When half of the thermocouples had reached $66^{\circ} \mathrm{C}$, the 0 -min holding time was reached. Turkey slices were held for 60 and 120 min thereafter. At Wisconsin, 4, 8, or 12 pans of sliced turkey meat (from oven loads of 2, 4, or 6 turkey rolls, respectively) were placed in a preheated $\left(82^{\circ} \mathrm{C}\right.$ ) hot-holdinq cabinet (Hotpack, Model 1242-4, Philadelphia, PA) until internal temperature of the slices reached $67^{\circ} \mathrm{C}$. Thereafter, slices were held for 60 or $120 \mathrm{~min}$. 
TIME AND TEMPERATURE DATA

Heating times for turkey roasts prepared in home convection ovens at Kansas and Illinois are shown in Table 3. Differences in cooking times between Kansas and Illinois may be due to variation in initial meat temperature and size of the rolls. Cooking times were siqnificantly ( $P<0.05)$ longer at the lower cooking temperatures. This trend was seen also in the foodservice studies at Wisconsin and Iowa. Representative heating curves for roasts cooked at the three oven temperatures in both home and institutional convection oven are shown in Figure 3.

TABLE 3. Heating Times for Turkey Roasts Prepared in Home Convection Ovens.

\begin{tabular}{|c|c|c|}
\hline Cooking Temperature & Kansas & Ilinois \\
\hline $\begin{array}{l}\left.{ }^{\circ} \mathrm{C}\right) \\
105 \\
135 \\
165\end{array}$ & $\begin{array}{l}\longleftarrow 54.0 \\
40.6 \\
32.2\end{array}$ & $\begin{array}{l}\overrightarrow{75} .6 \\
48.6 \\
36.9\end{array}$ \\
\hline
\end{tabular}

Time and temperature relationships were evaluated in terms of three oven loads and three oven temperatures at wisconsin. The times needed to reach the predetermined oven temperature at different oven loads were sianificantly different $(P<0.01)$ among the three oven loads of 2, 4, and 6 turkey rolls and three oven temperatures. As both the size of the oven load and the temperature of the oven increased, more time was needed to reach the predetermined oven temperature.

As shown in Figure 4, the cooking times for all turkey rolls to reach $77^{\circ} \mathrm{C}$ or above were significantly different $(P<0.01)$ among the three oven 


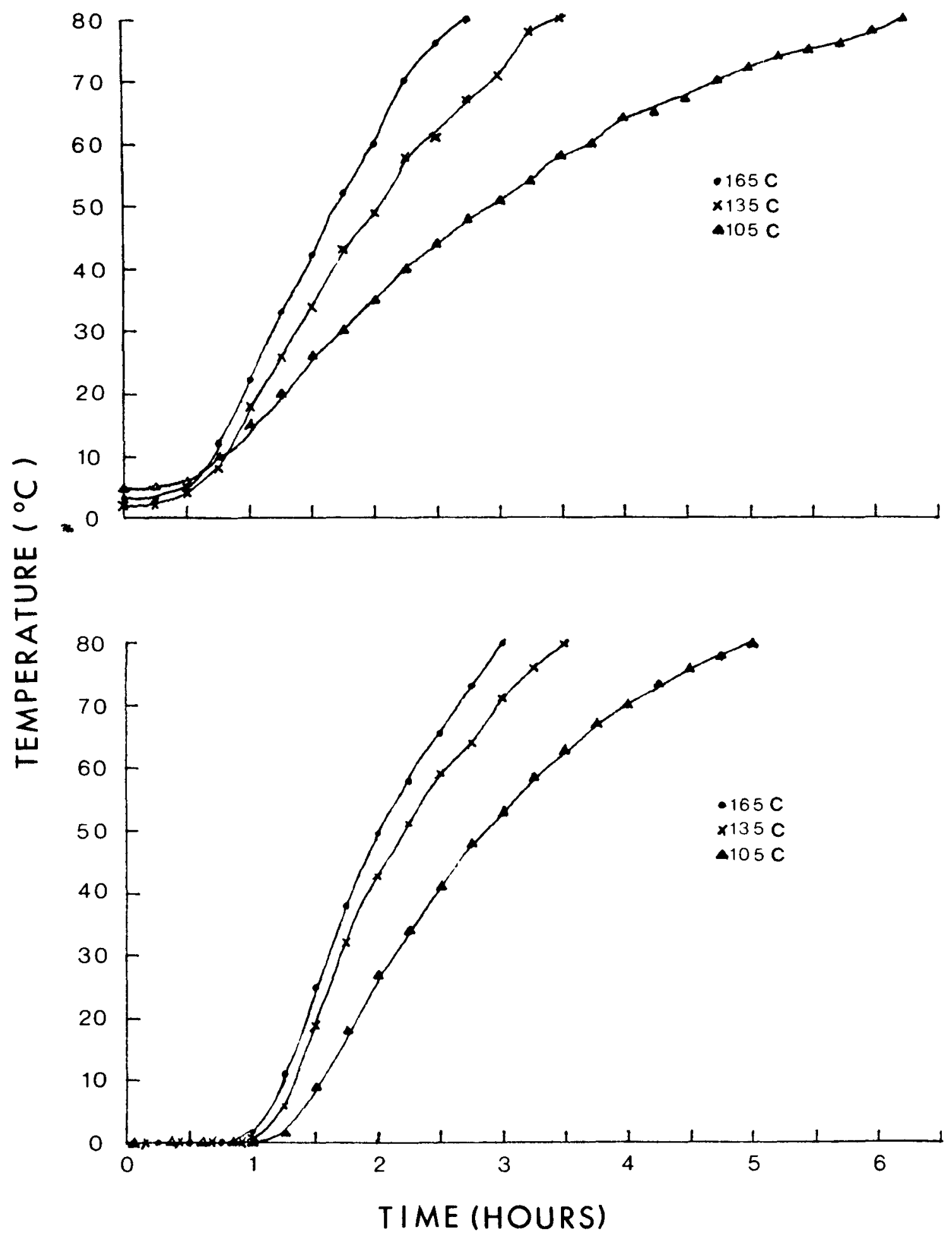

Figure 3. Representative Heating Curves for One Turkey Roast Cooked in a Home Convection Oven (above) and Two Turkey Roasts Cooked in an Institutional Convection oven (below). 


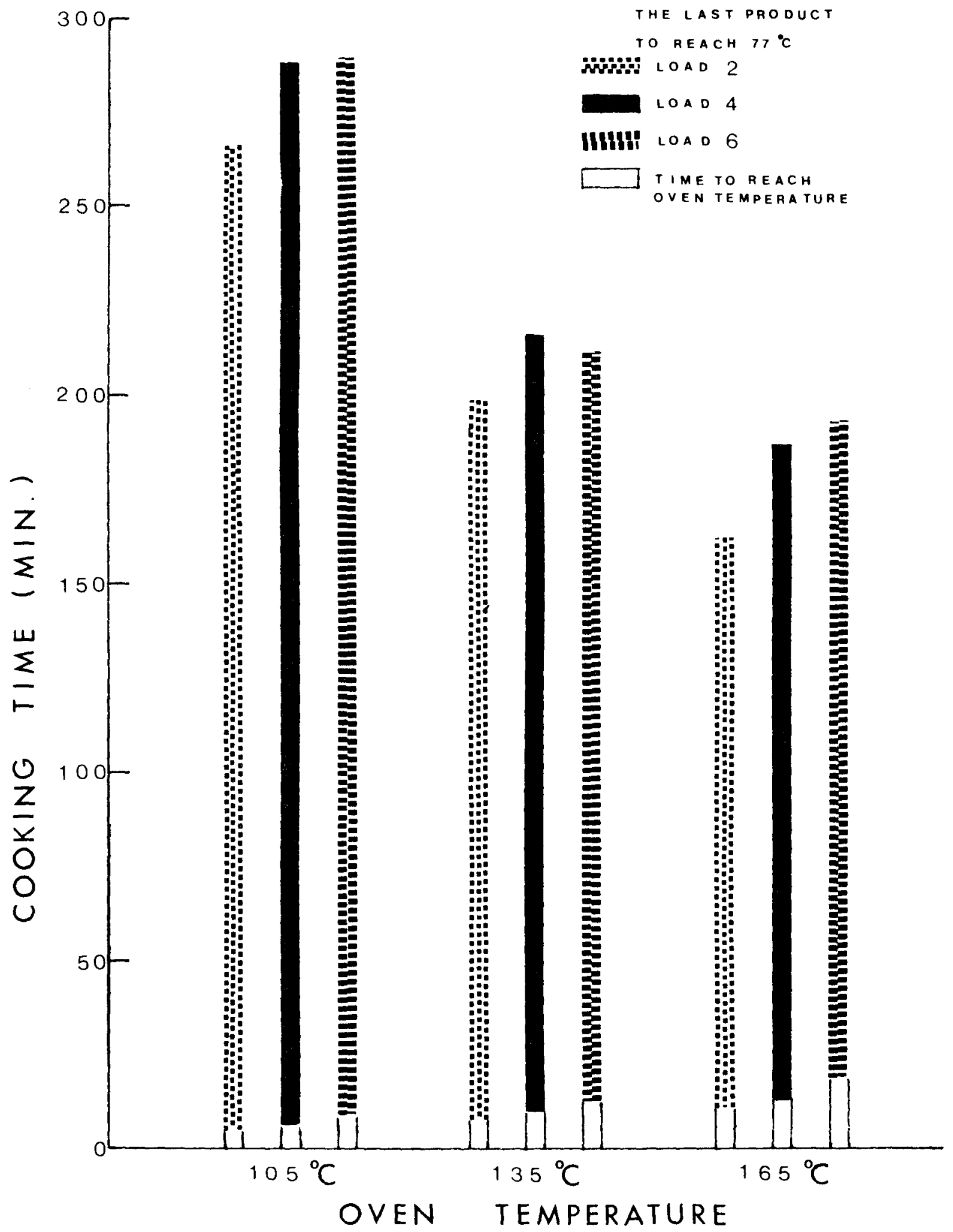

Figure 4. Time Needed to Reach Predetermined Oven Temperatures and Total Cooking Times for All Turkey Rolls to Reach $77^{\circ} \mathrm{C}$ or above in a Convection Oven When Usina Three Oven Loads and Three Oven Temperatures. 
temperature settinqs for all three oven loads. As the oven temperature increased, the cooking time decreased for all oven loads. The mean cooking times required by the three different oven loads were also significantly different $(P<0.01)$. However, times used for oven loads of 4 and 6 rolls at all three oven temperature settings were quite similar.

Further statistical analysis was undertaken to assess more specifically the time differences between individual loads and individual temperatures. Results indicated that there was a significant ( $P<0.01)$ time difference between oven loads of 2 and 4 turkey rolls, but there was no significant difference between oven loads of 4 and 6 rolls at three temperatures. The time differences between 105 and $135^{\circ} \mathrm{C}$ were more than $60 \mathrm{~min}$ for all three loads. The differences between 135 and $165^{\circ} \mathrm{C}$ were $36 \mathrm{~min}, 29.5 \mathrm{~min}$, and 18 min for oven loads of 2,4 , and 6 rolls, respectively. The differences between 105 and $135^{\circ} \mathrm{C}$ and also between 135 and $165^{\circ} \mathrm{C}$ were siqnificantly different $(P<0.01)$. When scheduling food production, it should be recoanized that oven temperature and oven load affect cooking time and must be considered in relationship to the desired sensory, nutritional, and microbial quality of the finished product as well as energy consumed in the process.

\section{PRODUCT YIELD}

Product yield as affected by oven load was determined only for roastina at $135^{\circ} \mathrm{C}$ at Missouri and Iowa (Table 4). The highest product yield was found when 4 rolls were heat processed simultaneously versus 2 or 6 rolls. The total processing losses (both evaporative and drip) were significantly greater $(P<0.05)$ when only 2 turkey rolls were in the oven cavity. Although relative humidity was not measured in these experiments, it probably increased as the 
number of turkey rolls increased, because they were heat processed in uncovered pans. This factor could account for differences in processing losses.

The mean weight values of turkey roll before and after heating and the percentage of yield after cooking (Wisconsin) are illustrated in Table 5 . The product yield was siqnificantly different $(P<0.01)$ amona three oven temperatures but not significantly different among three oven loads. The results for three oven loads agreed with those of Unk lesbay et al. (9) They concluded that the oven load did not influence product yield for $24,48,72$, or 96 sausage patties with convective heat processing. The Wisconsin study showed that lower oven temperatures for turkey roasts resulted in greater product yields (Table 5). However in a study of heat processing pizza crusts, Unk lesbay et al. (10) noted that the greatest food product yield was obtained with the highest oven temperature and the shortest heat processing time. The reasons for the differences in product yield, according to cooking time and temperature may be due to (a) the size and weight of products, because a turkey roll is much larger, heavier, and higher in moisture than a pizza crust or sausage patty; (b) different oven temperature settings and heat processinq times, because the time for cooking turkey rolls was at least tenfold greater than the time for heating pizza crust and sausage patties; and (c) different composition of food products; certain products are more likely to underqo case hardening, thereby influencing the rate of moisture diffusion. 
TABLE 4. Heat Processing Parameters for Turkey Roasts.

\begin{tabular}{|c|c|c|c|c|c|c|c|c|c|c|}
\hline \multirow{2}{*}{$\begin{array}{l}\text { Oven } \\
\text { Temp }\end{array}$} & \multirow[b]{2}{*}{$\mathrm{Na}^{\mathrm{a}}$} & \multirow{2}{*}{$\frac{\text { Load Size }}{\text { No }}$} & \multicolumn{2}{|c|}{$\begin{array}{l}\text { Initial } \\
\text { Mass (q) }\end{array}$} & \multicolumn{2}{|c|}{$\begin{array}{l}\text { Final } \\
\text { Mass (q) }\end{array}$} & \multicolumn{2}{|c|}{$\begin{array}{l}\text { Total Processing } \\
\text { Loss }(\%) \\
\end{array}$} & \multicolumn{2}{|c|}{$\begin{array}{l}\text { Yield } \\
(\%)\end{array}$} \\
\hline & & & Meanb & S.E.C & Meanb & S.E. C & Meanb & S.E.C & Mean b & S.E.C \\
\hline 135 & 3 & 2 & $10002^{2}$ & 23 & $7245^{2}$ & 62 & $27.54^{x}$ & 0.44 & $72.45^{2}$ & 0.44 \\
\hline 135 & 3 & 4 & $19996^{Y}$ & 25 & $15430^{Y}$ & 83 & $22.83^{2}$ & 0.35 & $77.16^{x}$ & 0.35 \\
\hline 135 & 3 & 6 & $30514^{x}$ & 144 & $22986^{X}$ & 123 & $24.66^{Y}$ & 0.44 & $75.33^{Y}$ & 0.44 \\
\hline
\end{tabular}

NOTES: Combined data from lowa State and University of Missouri

aRefers to the number of replications.

bMeans within a column followed by the same letter are not significantly different $(P<0.05)$.

CStandard error. 
TABLE 5. Mean Weights of Turkey Roasts Before and After Heatinq and the Percentage of $Y$ ield in a Convection Oven at Three Oven Loads and Three Oven Temperatures at Wisconsin.

\begin{tabular}{|c|c|c|c|c|}
\hline \multirow[b]{2}{*}{ Loads } & & \multicolumn{2}{|c|}{ Temperatures ${ }^{a}$} & \multirow{2}{*}{$165^{\circ} \mathrm{C}$} \\
\hline & & $105^{\circ} \mathrm{C}$ & $135^{\circ} \mathrm{C}$ & \\
\hline $2^{b}$ & $\begin{array}{l}\text { Before }(\mathrm{kg}) \\
\text { After }(\mathrm{kg}) \\
(\% \text { Yield })\end{array}$ & $\begin{array}{c}4.98+0.07 \mathrm{e} \\
3.89 \mp 0.10 \\
(78.04 \pm 3.28)\end{array}$ & $\begin{array}{c}4.95+0.15 \\
3.66 \pm 0.19 \\
(73.96 \pm 1.53)\end{array}$ & $\begin{array}{r}4.90 \pm 0.10 \\
3.54 \pm 0.15 \\
(72.15 \pm 1.72)\end{array}$ \\
\hline $4 \mathrm{C}$ & $\begin{array}{l}\text { Before }(\mathrm{kg}) \\
\text { After }(\mathrm{kg}) \\
(\% \text { Yield })\end{array}$ & $\begin{array}{c}5.07+0.19 \\
3.94 \mp 0.30 \\
(77.60 \mp 3.85)\end{array}$ & $\begin{array}{c}4.90 \pm 0.20 \\
3.55 \mp 0.21 \\
(72.46 \pm 2.32)\end{array}$ & $\begin{array}{r}4.94+0.16 \\
3.36 \pm 0.16 \\
(68.06 \pm 2.89)\end{array}$ \\
\hline $6^{d}$ & $\begin{array}{l}\text { Before }(\mathrm{kq}) \\
\text { After (kq) } \\
(\% \text { Yield })\end{array}$ & $\begin{array}{c}4.94+0.06 \\
3.86 \mp 0.12 \\
(78.13 \pm 2.44)\end{array}$ & $\begin{array}{c}4.96+0.13 \\
3.55+0.16 \\
(71.53 \pm 2.76)\end{array}$ & $\begin{array}{r}4.92+0.09 \\
3.44 \pm 0.14 \\
(69.77 \pm 2.29)\end{array}$ \\
\hline
\end{tabular}

a The mean yield dependent on oven temperature was significantly different ( $P<0.01)$.

$b$ Mean of 2 rolls.

c Mean of 4 rolls.

d Mean of 6 rolls.

e Standard deviation.

SENSORY STUDIES

Oven roasting temperature and reheating effects.

A split plot design was used to analyze the sensory data for variances. Turkey rolls evaluated at four laboratories were similar in sensory characteristics after roasting at 105,135 , or $165^{\circ} \mathrm{C}$ with or without $24-\mathrm{hr}$ chilling and reheating. Juiciness was a sensory characteristic that was altered significantly $(P<0.05)$ that would have implications for consumers (Figure 5). The least juicy roasts were those cooked at $165^{\circ} \mathrm{C}$ and reheated. However, when the roasting end-point temperature was $80^{\circ} \mathrm{C}$ (IIIinois and Kansas), samples of turkey rolls cooked at $165^{\circ} \mathrm{C}$ and reheated were less juicy, only when compared to turkey rolls that were roasted at 105 and $135^{\circ} \mathrm{C}$ and not reheated. 

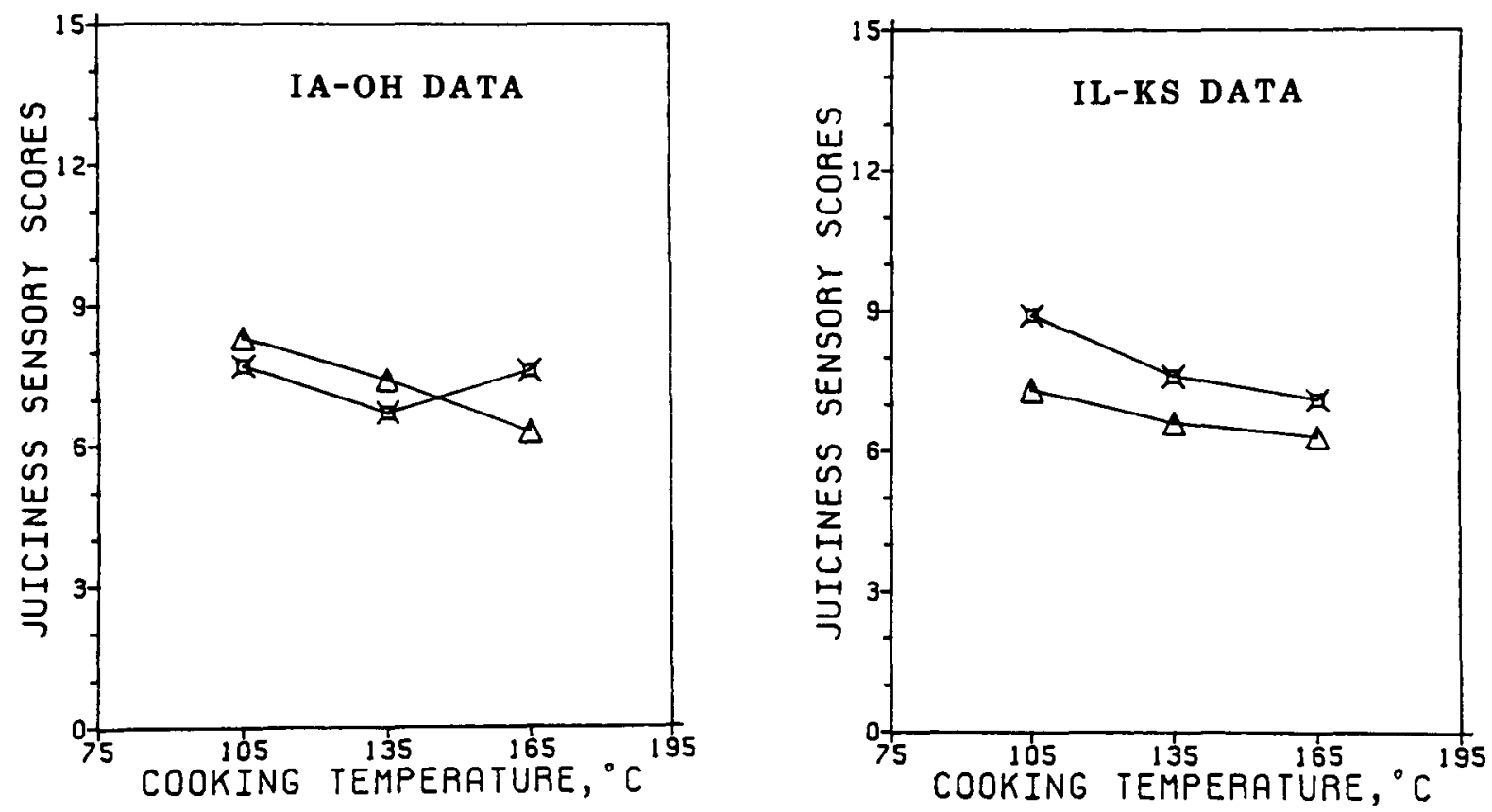

Fig. 5 Mean Scores for Juiciness in Turkey Roasts Cooked at Three Oven Temperatures, with and without Chilling and Reheatina.

$$
\begin{aligned}
\Delta & =\text { chill } \\
x & =\text { no chill }
\end{aligned}
$$

The range of mean scores for chew counts was 12.9 to 22.8 (Table 6). This measurement is based on counts of actual chews of standardized samples at a standardized rate, and variations in individuals' mouth structures and dentures would be reflected. This range is considered small for such measurements, making the differences unimportant $(11,12)$.

For the other characteristics evaluated, some differences were statistically significant (Table 6). However, differences were small (ranges on ballots of 0.8 to $1.4 \mathrm{~cm}$ on $15-\mathrm{cm}$ scales) as shown in Figures 6 through 9 . 
TABLE 6. Least Square Means Showing Treatment Effects on Sensory Parameters of Turkey Roasts.

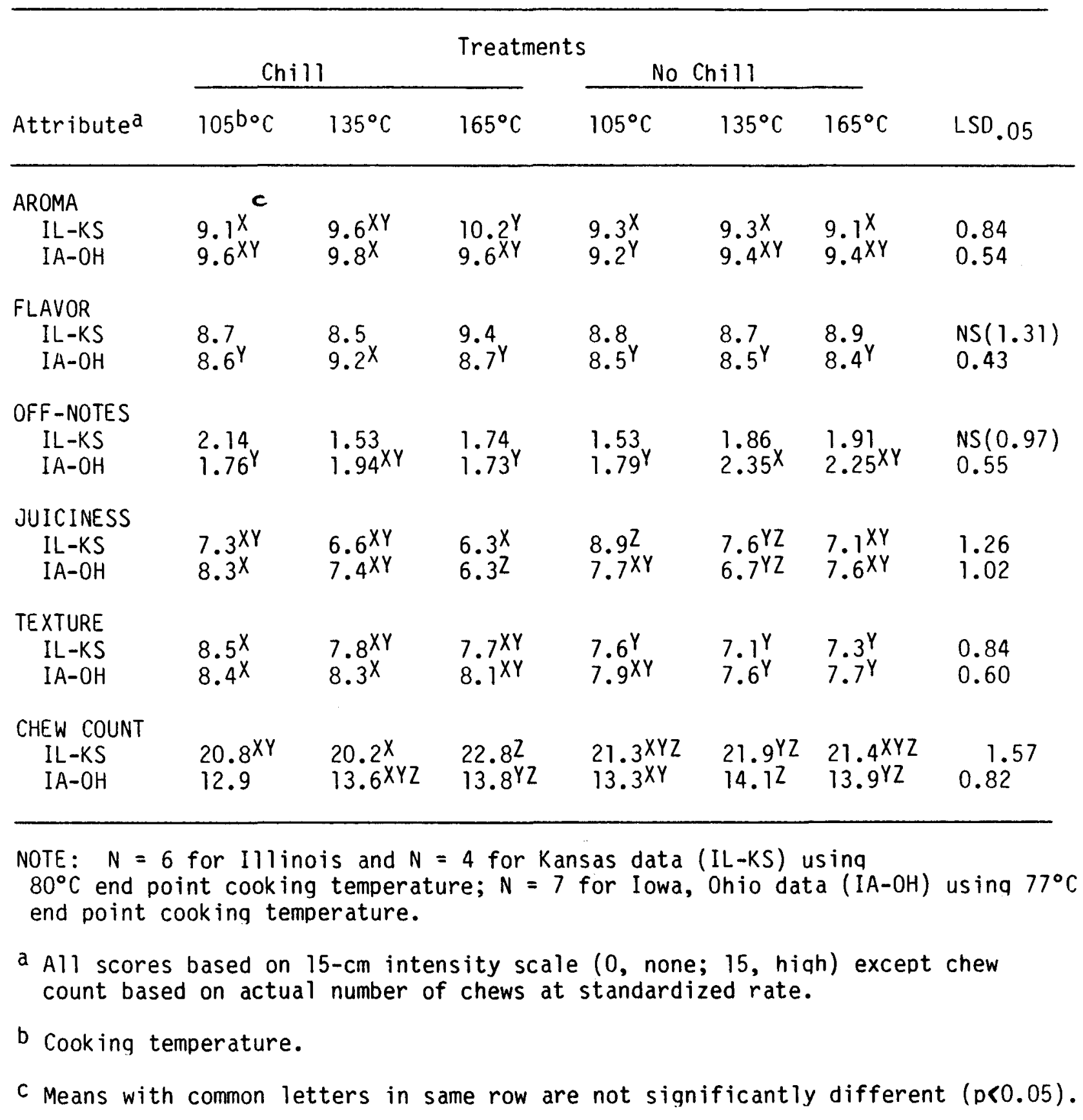



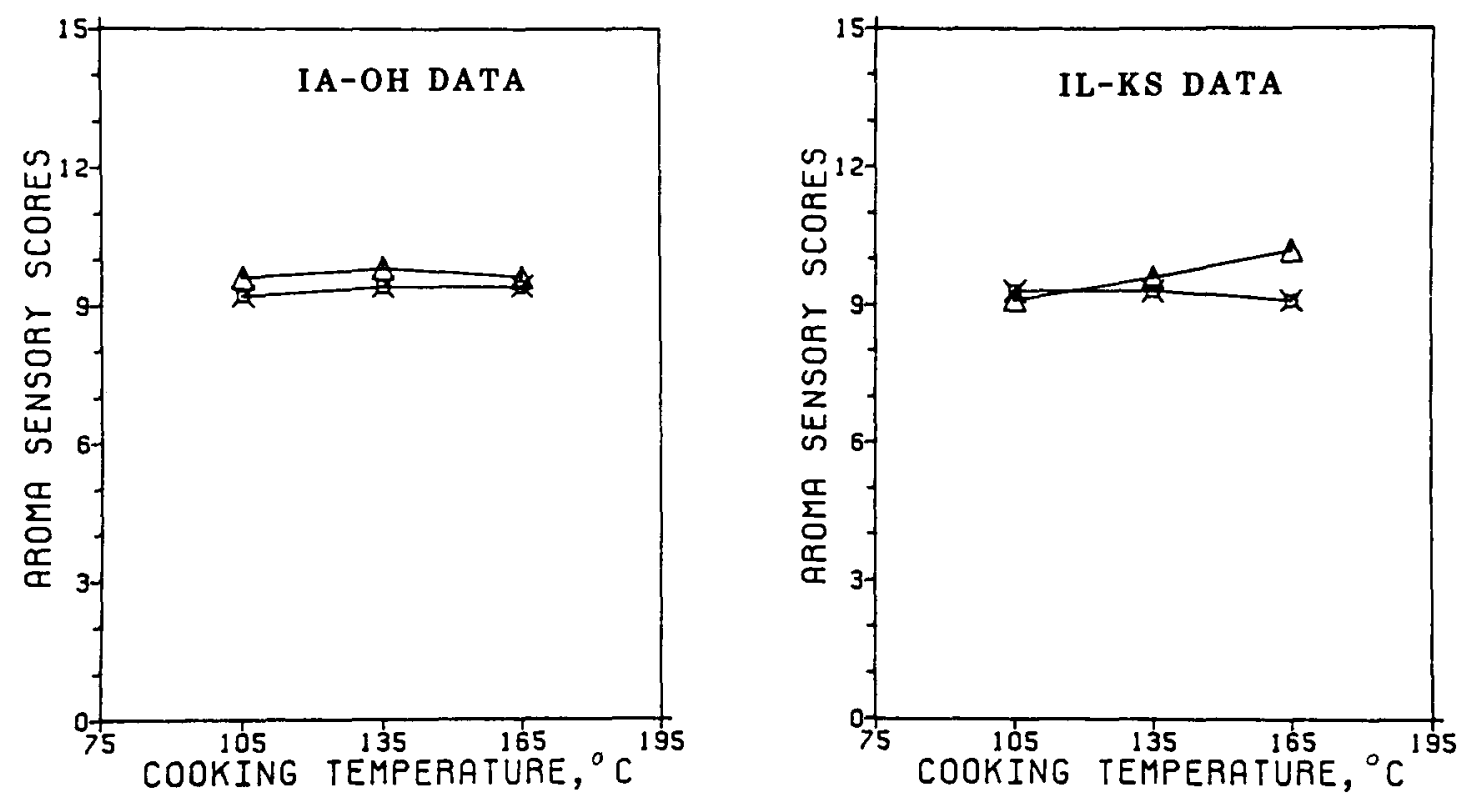

Fig. 6 Mean Scores for Roasted Aroma in Turkey Roasts Cooked at Three Oven Temperatures, with and without Chillina and Reheating.
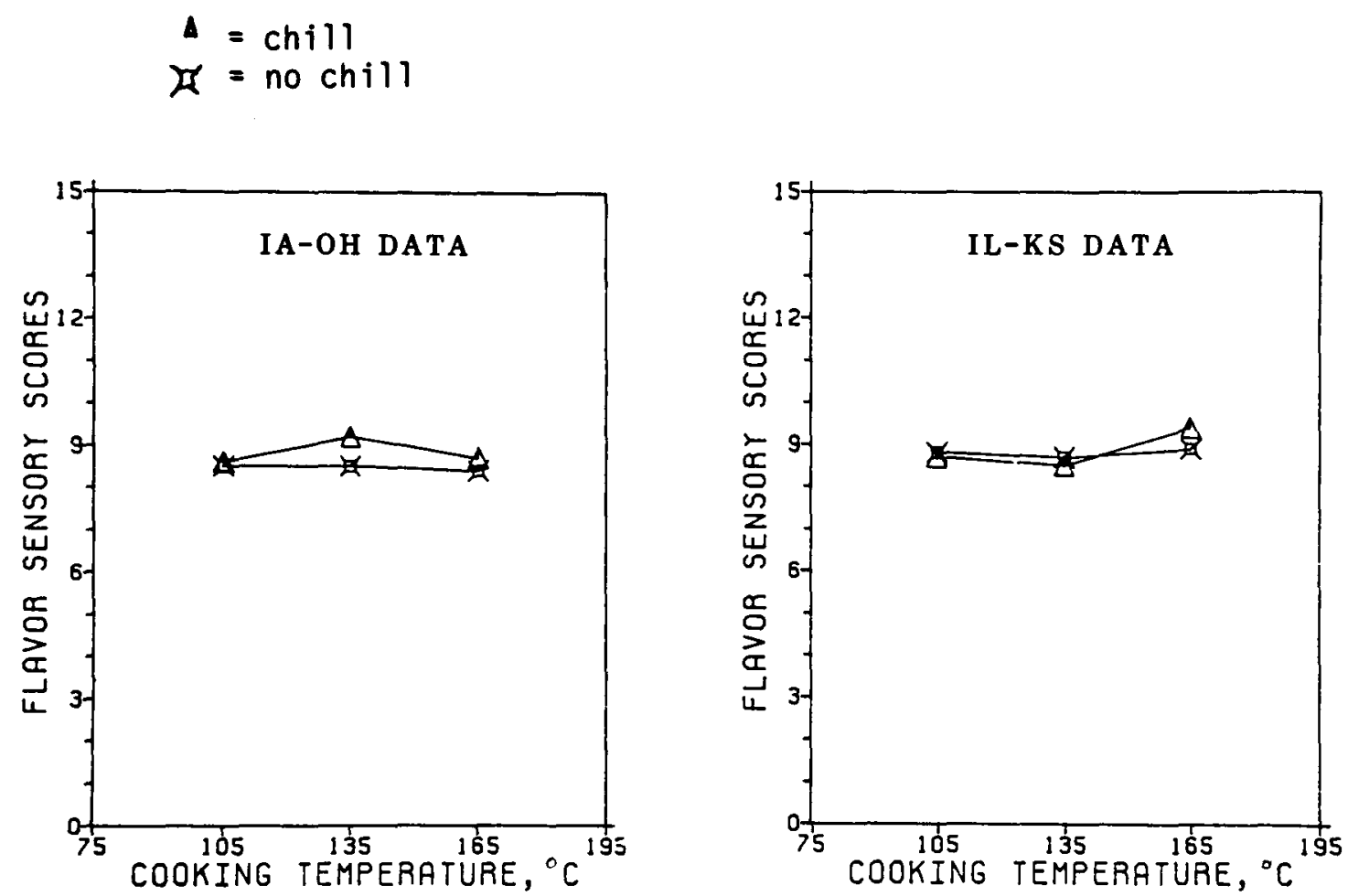

Fig. 7 Mean Scores for Meaty, Cooked Flavor in Turkey Roasts Cooked at Three oven Temperatures, with and without Chilling and Reheating.

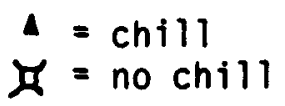



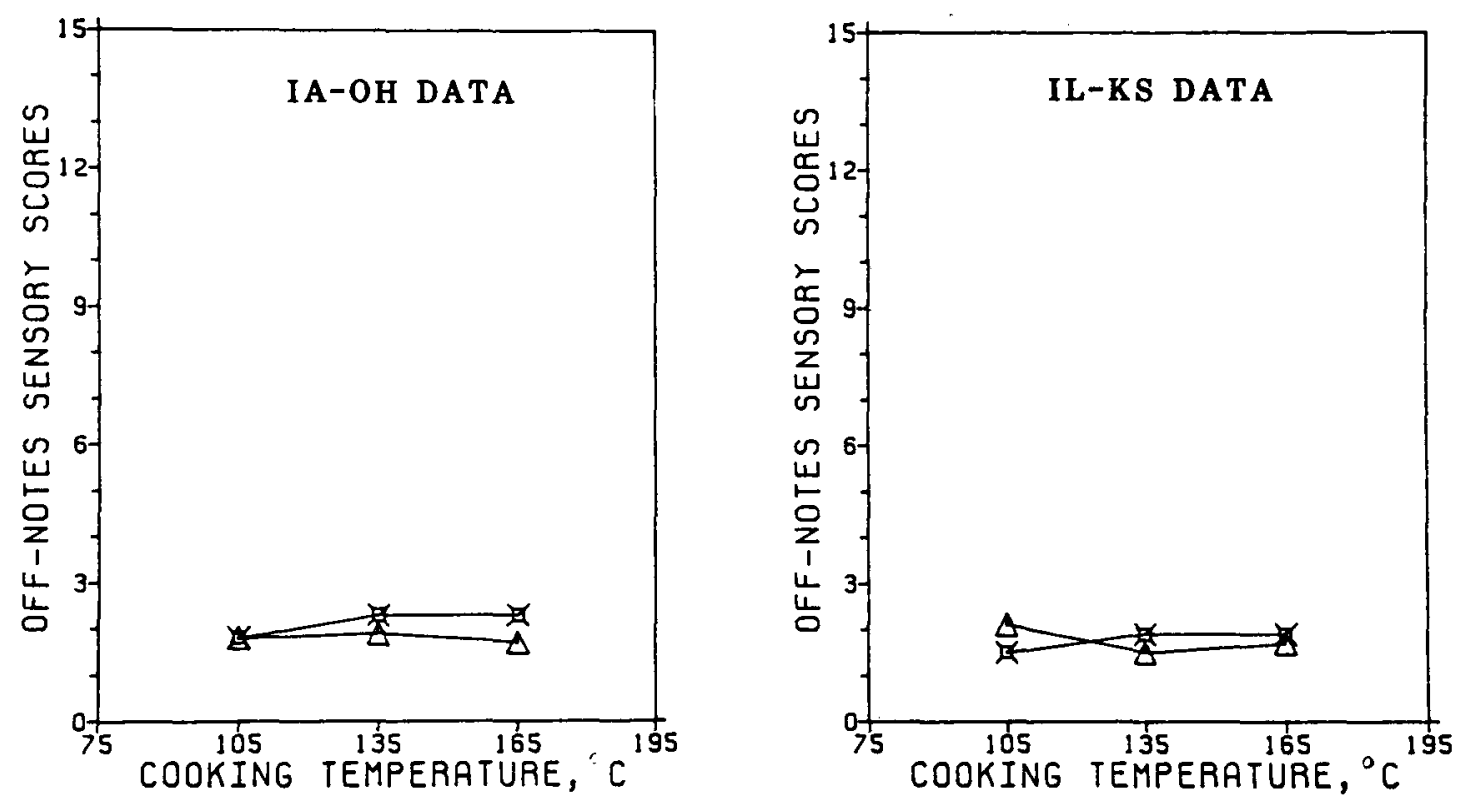

Fig. 8 Mean Scores for Off-Notes in Turkey Roasts Cooked at Three Oven Temperatures, with and without Chilling and Reheating.
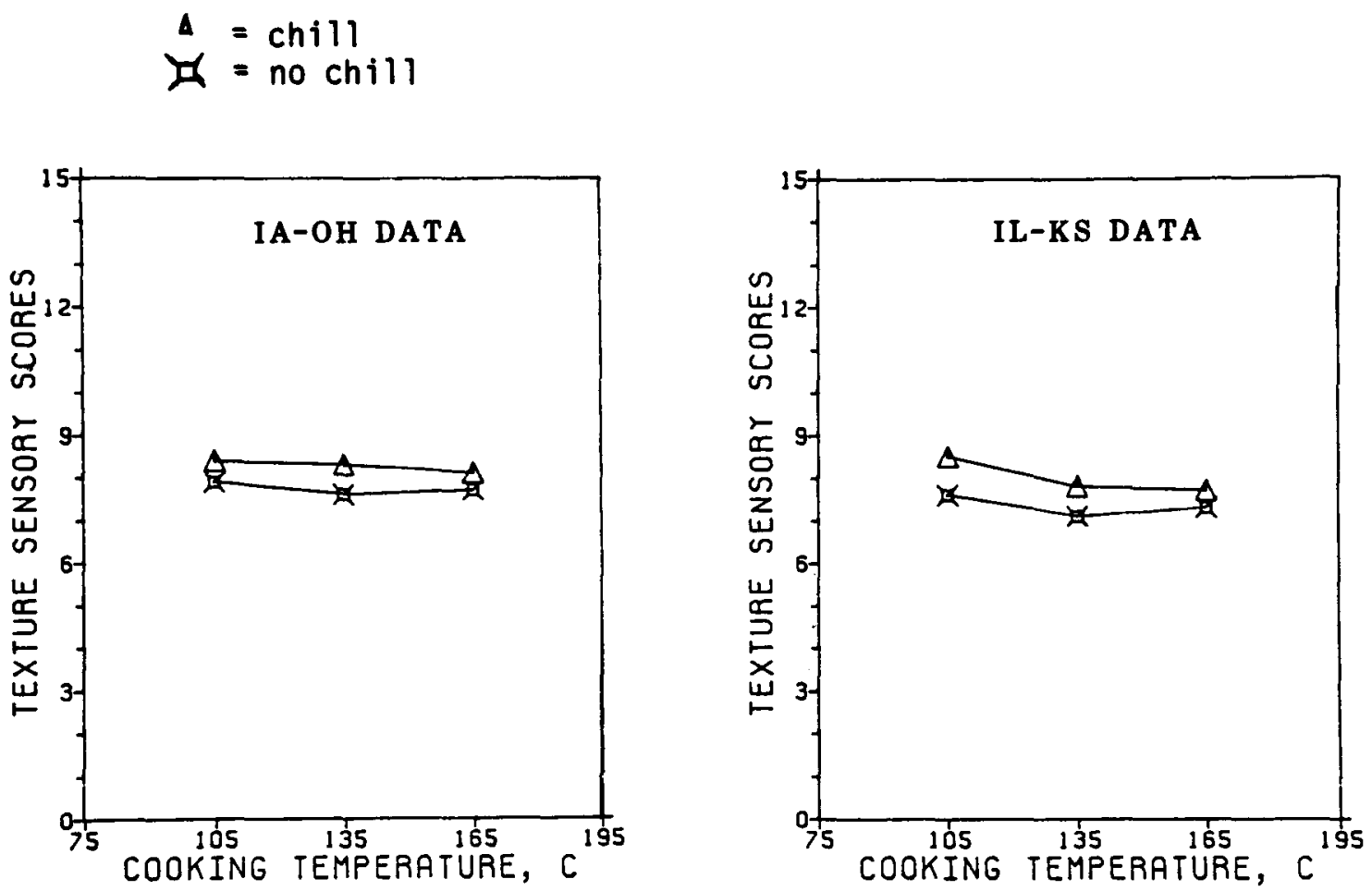

Fig. 9 Mean Scores for Texture in Turkey Roasts Cooked at Three Oven Temperatures, with and without Chilling and Reheating.

$$
\begin{aligned}
\Delta & =\text { chill } \\
\boldsymbol{A} & =\text { no chill }
\end{aligned}
$$


Holding time effects

Juiciness decreased significantly $(P<0.05)$ as hot-holding proqressed. The difference was significant between 0 and $60 \mathrm{~min}$, and roasts cooked to $77^{\circ} \mathrm{C}$ (Iowa and Ohio) also became progressively less juicy $(P<0.05)$ between 60 and 120 min (Figure 10). Other sensory scores were within such a small range of the total scale that, although some differences were statistically significant (Table 7), these would not likely be discernible by the general population on a first trial basis (Figures 11 and 12). This is because trained panelists are expected to be more discerning than the general population, and generalizing to the consumer on the basis of small differences detected by trained panelists could be risky (13). Sensory scientists are required to use

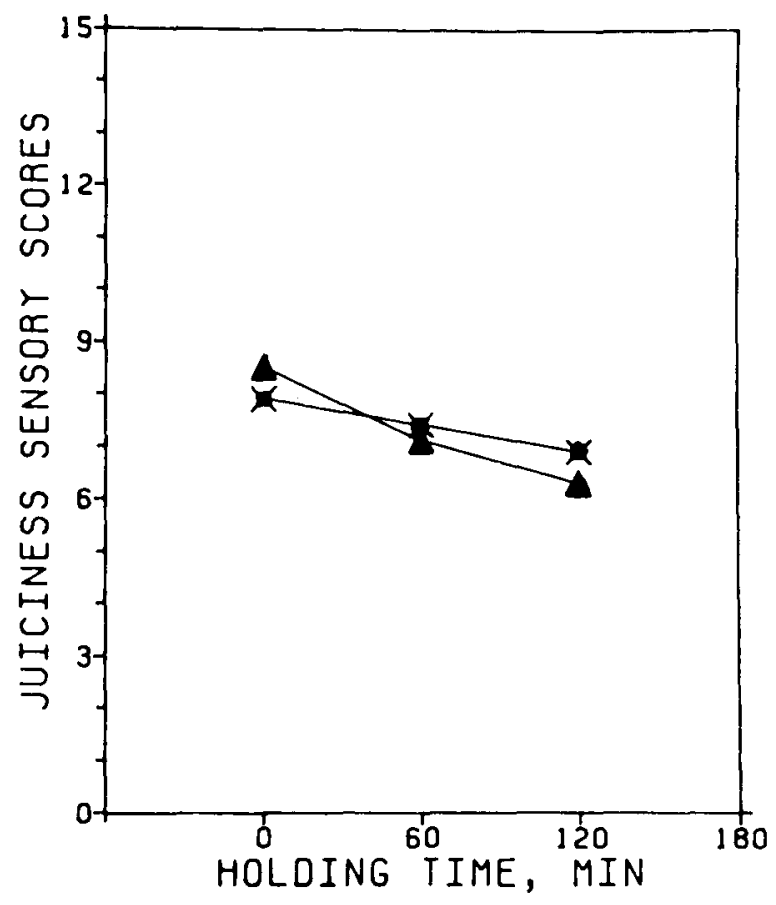

Fig. 10 Mean Scores Pooled for A11 Treatment Combinations for Juiciness of Turkey Roasts After Hot-Holding 0,60 and 120 min at $105^{\circ} \mathrm{C}$.

$$
\begin{aligned}
& \Delta=I L-K N \\
& x=I A-O H
\end{aligned}
$$


TABLE 7. Least Square Means Showing Holding Time Effects on Sensory Parameters of Turkey Roasts.

\begin{tabular}{|c|c|c|c|c|}
\hline \multirow[b]{2}{*}{ Attribute } & \multicolumn{3}{|c|}{ Holding Time (Min) } & \multirow[b]{2}{*}{ LSD .05} \\
\hline & 0 & 60 & 120 & \\
\hline $\begin{array}{l}\text { AROMA } \\
\text { IL-KS } \\
\text { IA-OH }\end{array}$ & $\begin{array}{l}9.3^{x^{6}} \\
9.0^{x}\end{array}$ & $\begin{array}{l}9.2^{X} \\
9.6^{Y}\end{array}$ & $\begin{array}{r}9.8^{Y} \\
10.0^{Z}\end{array}$ & $\begin{array}{l}0.45 \\
0.36\end{array}$ \\
\hline $\begin{array}{l}\text { FLAVOR } \\
\text { IL-KS } \\
\text { IA-OH }\end{array}$ & $\begin{array}{l}8.9 \\
8.5\end{array}$ & $\begin{array}{l}8.9 \\
8.6\end{array}$ & $\begin{array}{l}8.6 \\
8.9\end{array}$ & $\begin{array}{l}\text { NS }(0.58) \\
\text { NS }(0.39)\end{array}$ \\
\hline $\begin{array}{c}\text { OFF - NOTES } \\
\text { IL-KS } \\
\text { IA-OH }\end{array}$ & $\begin{array}{l}1.5^{x} \\
1.9^{x}\end{array}$ & $\begin{array}{l}1.8^{X Y} \\
2.0\end{array}$ & $\begin{array}{l}2.0^{Y} \\
2.1\end{array}$ & $\begin{array}{l}0.44 \\
\text { NS }(0.33)\end{array}$ \\
\hline $\begin{array}{c}\text { JUICINESS } \\
\text { IL-KS } \\
\text { IA-OH }\end{array}$ & $\begin{array}{l}8.5^{X} \\
7.9^{x}\end{array}$ & $\begin{array}{l}7.1^{Y} \\
7.4^{Y}\end{array}$ & $\begin{array}{l}6.3^{Y} \\
6.9^{2}\end{array}$ & $\begin{array}{l}0.90 \\
0.45\end{array}$ \\
\hline $\begin{array}{r}\text { TEXTURE } \\
\text { IL-KS } \\
\text { IA-OH }\end{array}$ & $\begin{array}{l}7.3 \\
7.8^{x}\end{array}$ & $\begin{array}{l}7.9 \\
8.0^{X Y}\end{array}$ & $\begin{array}{l}7.6 \\
8.2^{Y}\end{array}$ & $\begin{array}{l}\operatorname{NS}(0.69) \\
0.32\end{array}$ \\
\hline $\begin{array}{l}\text { CHEW COUNT } \\
\text { IL-KS } \\
\text { IA-OH }\end{array}$ & $\begin{array}{l}20.4^{x} \\
14.0^{x}\end{array}$ & $\begin{array}{l}21.2^{X} \\
13.3^{Y}\end{array}$ & $\begin{array}{l}22.6_{Y}^{Y} \\
13.4^{X Y}\end{array}$ & $\begin{array}{l}0.98 \\
0.61\end{array}$ \\
\hline
\end{tabular}

NOTE: $N=6$ for Illinois and $N=4$ for Kansas data $(1 L-K S) ; N=7$ for Iowa, Ohio $(\mathrm{IA}-\mathrm{OH})$ data.

a All scores based on $15-\mathrm{cm}$ intensity scale (0, none; 15 , high) except chew count based on actual number of chews at standardized rate.

b Means with common letters in same row are not sianificantly different $(p<0.05)$. 

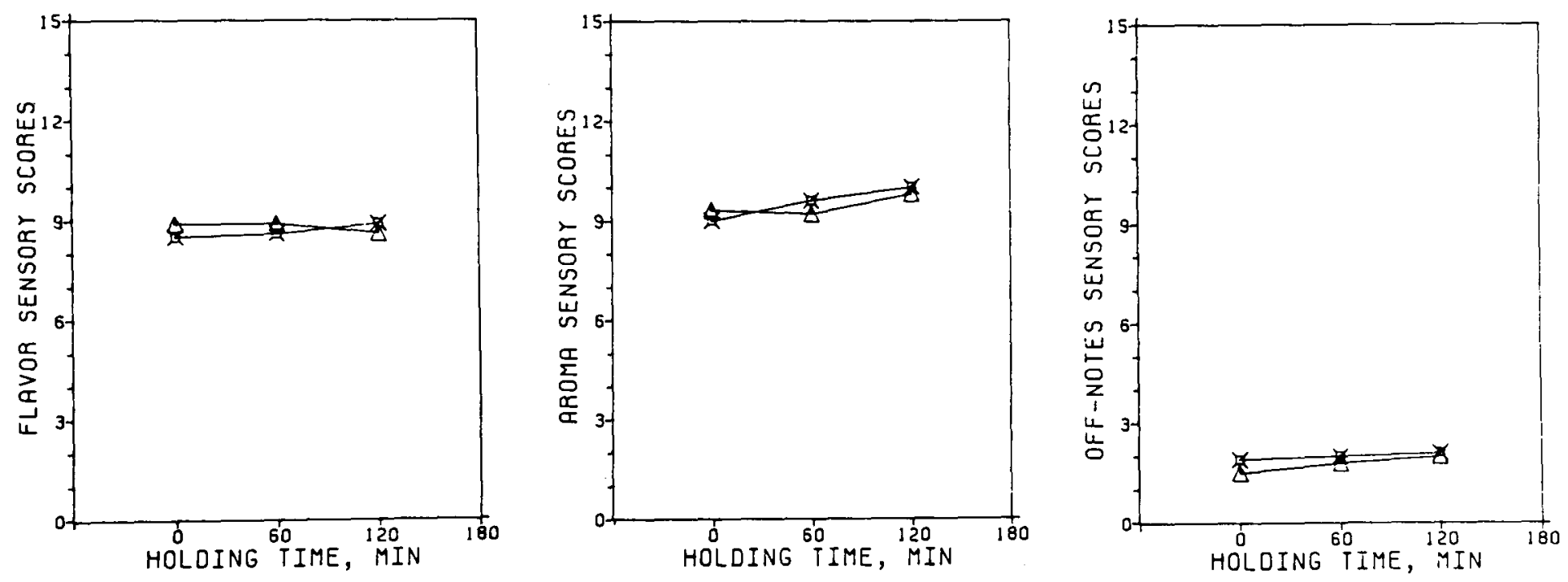

Fig. 11 Mean Scores Pooled for All Treatment Combinations for Sensory Flavor Attributes of Turkey Roasts After Hot-Holding 0,60 , and 120 min at 105'
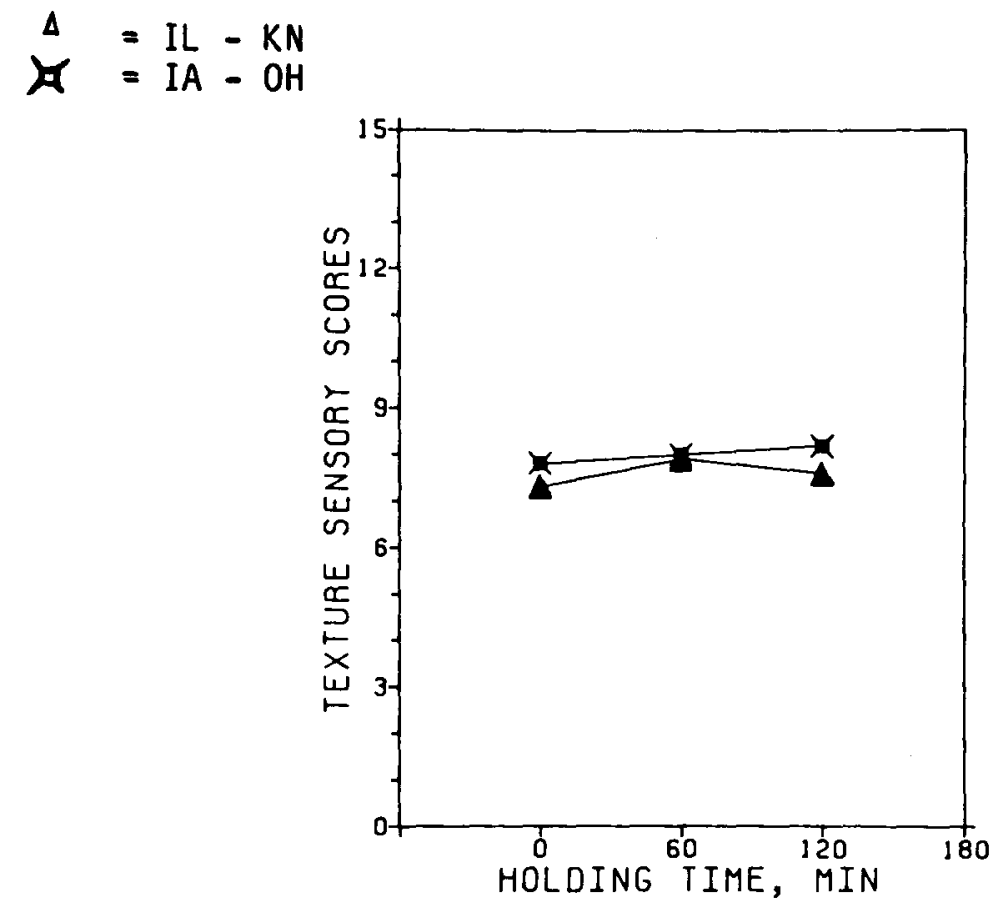

Fig. 12 Mean Scores Pooled for All Treatment Combinations for Crumbly, Mealy Texture of Turkey Roasts After Hot-Holding 0, 60, and $120 \mathrm{~min}$ at $105^{\circ} \mathrm{C}$.<smiles>CC(C)(C)[Al]#[W]O</smiles> 
a pragmatic approach, generally utilizing parametric statistical methods (ANOVA) even though the scaling data might not be distributed normally. Thus, a sensory scientist should consider the analysis only a "rough and ready" approach (14). Under those circumstances, one could go amiss placing great emphasis upon sensory scores with small variances even though the differences are statistically significant.

\section{Other Observations}

One of the interesting aspects of this study, from a sensory methodological perspective, involved a comparison of data usina panels selected by two procedures. The researchers at each location trained taste panelists equally at that location. Iowa and Ohio each selected panelists, trained them, and used the same panelists for each evaluation period throughout the study. On the other hand, Illinois and Kansas each trained 12 panelists to serve as a pool of trained panelists, and for each evaluation period selected a smaller, constant number of panelists at random to serve as the evaluators.

Comparisons of the variances for the panels using Hartley's F-max test for homogeneity of variances (15), normalized to account for differences in panel size at each of the four Agricultural Experiment Stations, did not indicate differences related to training one group and selecting a portion of the aroup for the individual sessions versus selecting one constant qroup and trainina and using the entire group each session (Table 8). Differences ( $0<0.05)$ in variances among groups for flavor could be related to use of wider sections of the scale to assess the attributes by some groups (Table 8). Another possibility is use of different portions of the scale by different aroups. 
TABLE 8. Experimental Error Variances of Sensory Data.

\begin{tabular}{|c|c|c|c|c|c|c|c|}
\hline Station & $\begin{array}{c}\text { Roasted } \\
\text { Aroma }\end{array}$ & Juiciness & $\begin{array}{l}\text { Mealy or } \\
\text { Fibrous } \\
\text { Texture }\end{array}$ & $\begin{array}{l}\text { Chew } \\
\text { Count }\end{array}$ & Flavor & $\begin{array}{l}\text { Off- } \\
\text { notes }\end{array}$ & $\begin{array}{l}\text { Panel } \\
\text { Size }\end{array}$ \\
\hline ILLINOIS & 8.05 & 15.69 & 6.63 & 32.52 & 9.11 & 17.16 & 6 \\
\hline KANSAS & 6.21 & 15.72 & 7.16 & 19.11 & 22.36 & 4.25 & 4 \\
\hline IOWA & 4.58 & 13.82 & 6.36 & 10.68 & 2.15 & 4.79 & 6 \\
\hline $\mathrm{OHIO}$ & 3.80 & 17.70 & 4.02 & 8.88 & 3.51 & 4.25 & 9 \\
\hline$F_{\text {max }}=$ & 2.12 & 1.28 & 1.73 & 1.79 & $10.41^{\star}$ & 4.04 & \\
\hline
\end{tabular}

*The $5 \%$ critical point for the $F_{\text {max }}$ test for four Aqricultural Experiment Stations with of $=10$ is 5.67 . Phus flavor was the only sensory attribute for which a significant difference existed among the four Experiment Stations.

Training is essential to develop a common lanquaqe to describe the characteristics and to improve a panel's ability to make consistent judgments. Each panel can meet these criteria, yet the degree to which one group interprets how intensely the standard is found in a product can easily differ with another group of panelists. One of the difficulties in combining data using different panels will always be this very matter. Consistency of performance might be improved by tight definition and control of reference standards for each attribute. Some differences in interpreting references and arriving at a consensus regarding their usaqe (16) are inherent in any study using human instruments, even though mean scores were used for the actual data analyses. 
NUTRITIONAL STUDIES

Thiamin content of raw white turkey muscle analyzed at 111 inois was 77 mcg/100g. This is comparable to previously reported values $(17,18)$. Raw turkey meat at the other Agricultural Experiment Stations was not analyzed.

Thiamin content of the cooked white meat was analyzed at Kansas, Illinois, Wisconsin, and Iowa. Results are shown in Table 9 and Fiaure 13 (Illinois only). Heat treatment, e.q. oven temperature, as well as chillina cooked roasts, siqnificantly $(P<0.001)$ affected the thiamin content of turkey meat on the wet-weight basis. As can be seen in Table 9, the values for Illinois are

TABLE 9. Thiamin Contenta (mcq/100q) of Cooked White Turkey Meat.

\begin{tabular}{|c|c|c|c|c|c|}
\hline $\begin{array}{l}\text { Cooking } \\
\text { Temperature }\left({ }^{\circ} \mathrm{C}\right) \\
\text { and Chill State }\end{array}$ & $\begin{array}{l}\text { Holding } \\
\text { Time } \\
\text { (min) }\end{array}$ & Kansas & Mlinois & Wisconsin & Towa \\
\hline $105 N C$ & $\begin{array}{r}0 \\
60 \\
120\end{array}$ & $\begin{array}{l}53.3 \\
58.8 \\
58.8\end{array}$ & $\begin{array}{l}53.7 \\
53.0 \\
52.3\end{array}$ & $\begin{array}{l}57.7 \\
60.3 \\
62.3\end{array}$ & $\begin{array}{l}35.2 \\
34.5 \\
35.3\end{array}$ \\
\hline $105 \mathrm{C}$ & $\begin{array}{r}0 \\
60 \\
120\end{array}$ & $\begin{array}{l}37.7 \\
43.0 \\
40.3\end{array}$ & $\begin{array}{l}65.0 \\
62.7 \\
60.3\end{array}$ & $\begin{array}{l}\text { NOb } \\
\text { ND } \\
\text { ND }\end{array}$ & $\begin{array}{l}33.4 \\
32.1 \\
33.9\end{array}$ \\
\hline $135 \mathrm{NC}$ & $\begin{array}{r}0 \\
60 \\
120\end{array}$ & $\begin{array}{l}40.7 \\
44.3 \\
42.7\end{array}$ & $\begin{array}{l}51.7 \\
50.3 \\
50.0\end{array}$ & $\begin{array}{l}43.0 \\
51.7 \\
39.0\end{array}$ & $\begin{array}{l}34.4 \\
33.7 \\
35.0\end{array}$ \\
\hline $135 \mathrm{C}$ & $\begin{array}{r}0 \\
60 \\
120\end{array}$ & $\begin{array}{l}39.0 \\
42.0 \\
35.0\end{array}$ & $\begin{array}{l}55.7 \\
56.0 \\
52.3\end{array}$ & $\begin{array}{l}\text { ND } \\
\text { ND } \\
\text { NO }\end{array}$ & $\begin{array}{l}34.4 \\
34.4 \\
34.7\end{array}$ \\
\hline $165 \mathrm{NC}$ & $\begin{array}{r}0 \\
60 \\
120\end{array}$ & $\begin{array}{l}38.0 \\
30.0 \\
35.7\end{array}$ & $\begin{array}{l}49.0 \\
47.7 \\
47.0\end{array}$ & $\begin{array}{l}45.3 \\
55.7 \\
36.3\end{array}$ & $\begin{array}{l}33.8 \\
31.8 \\
31.4\end{array}$ \\
\hline $165 \mathrm{C}$ & $\begin{array}{r}0 \\
60 \\
120\end{array}$ & $\begin{array}{l}46.3 \\
42.3 \\
37.0\end{array}$ & $\begin{array}{l}50.0 \\
47.3 \\
45.0\end{array}$ & $\begin{array}{l}\text { ND } \\
\text { ND } \\
\text { ND }\end{array}$ & $\begin{array}{l}34.0 \\
29.5 \\
30.5\end{array}$ \\
\hline
\end{tabular}




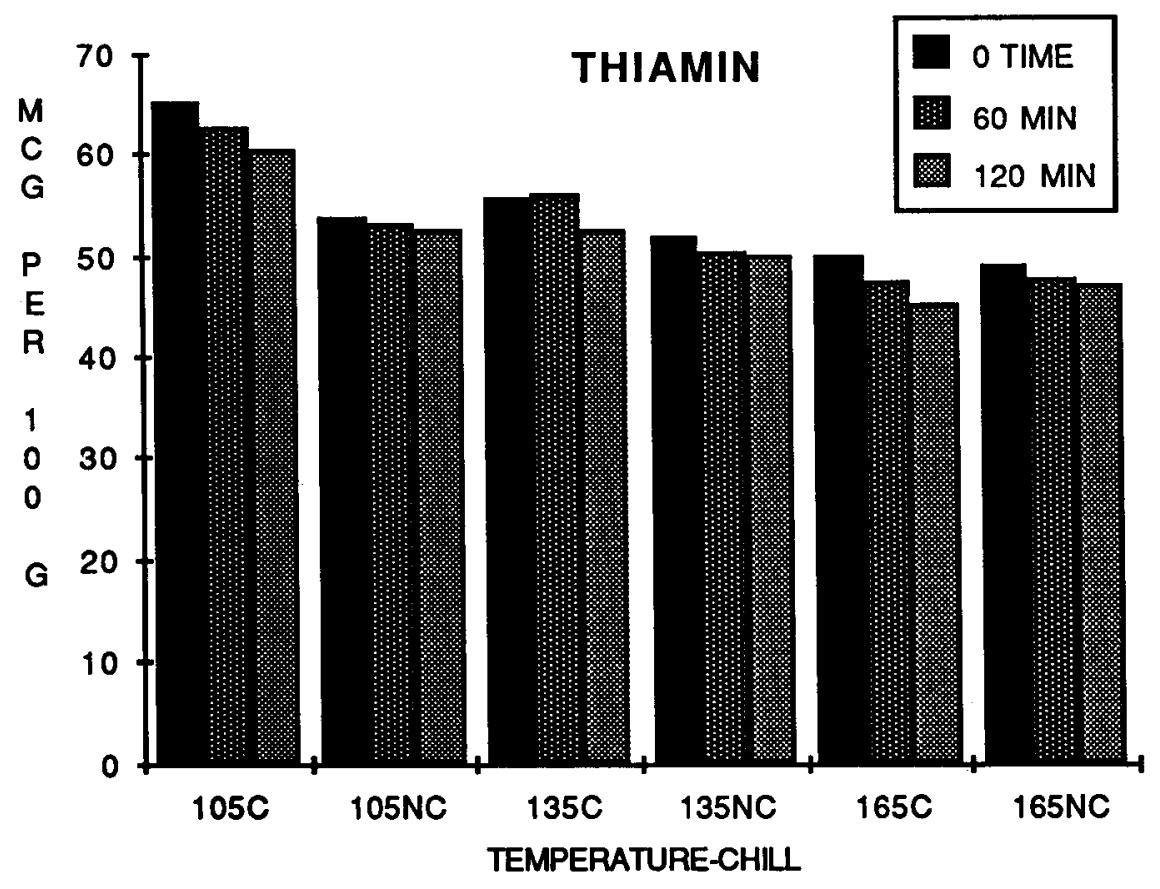

Figure 13. Thiamin Content of White Turkey Meat at Illinois. Note: Chill state (Nonchill =NC, Chill for $24 \mathrm{hr} .=\mathrm{C}$ ) prior to hot-holding. Thiamin content was on the wet-weight basis.

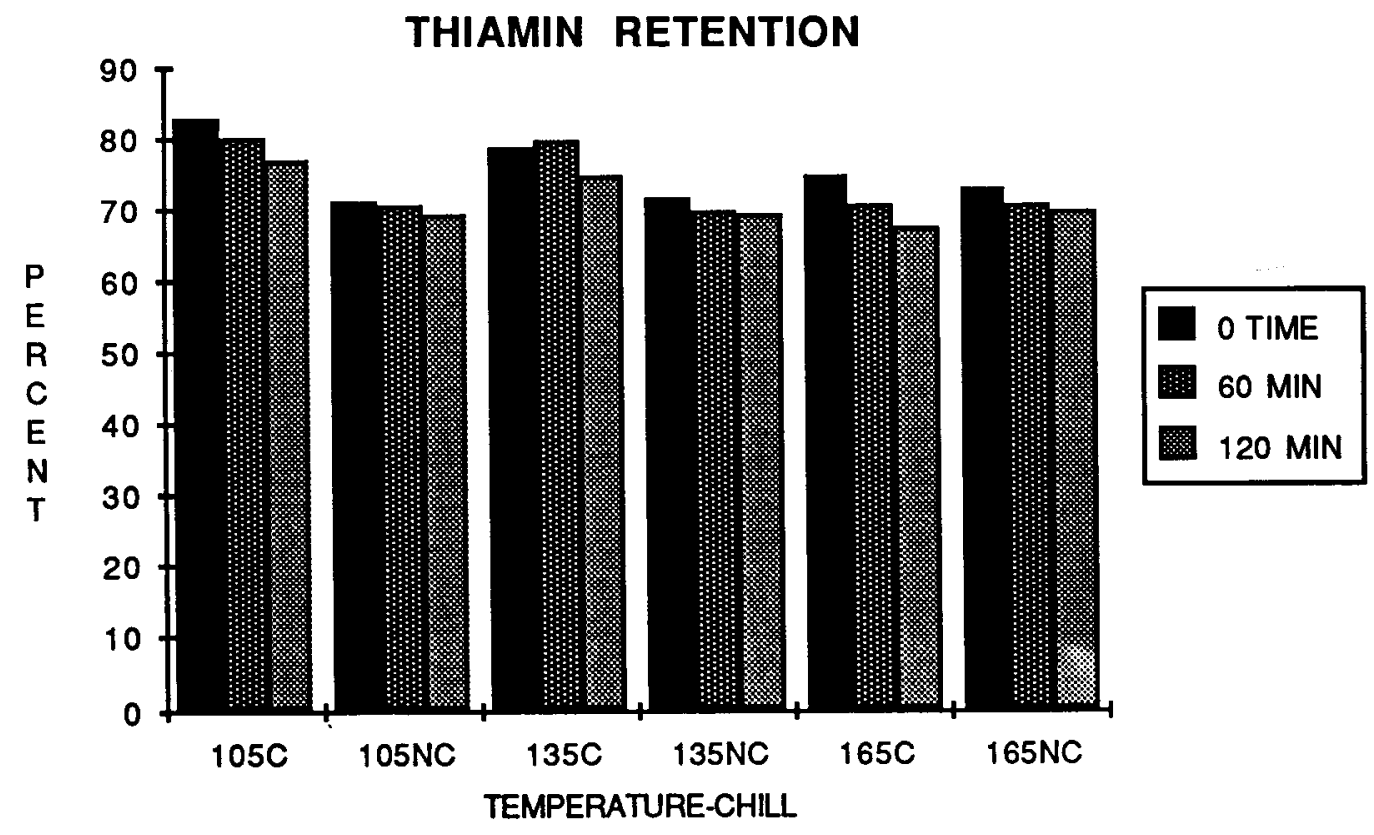

Figure 14. Percentage Thiamin Retention in White Turkey Meat at Illinois. Note: Chill state (nonchill $=N C$, chill for $24 \mathrm{hr}=\mathrm{C}$ ) prior to hot-holding. 
generally higher than for the other three states, although on the moisture and fat-free basis, values are comparable. Thiamin content in cooked turkey decreased significantly $(P<0.05)$ with increasina temperature; percentage thiamir retention followed a similar trend (Figure 14, Illinois only). The effect of chilling prior to reheating and holding versus hot-holding directly after cookir was significant $(P<0.001)$. In the 111 inois study, thiamin content and retentior the chilled meat was higher than in the nonchilled meat. Neither the data from Iowa nor Kansas showed a difference in thiamin retention due to chilling of the meat.

Holding time following cooking or reheating significantly influenced thiamir content. In the Illinois study, there was a consistent effect of holdina time: decrease in thiamin content was observed as holdina time increased.

Wisconsin and Iowa used institutional methods of preparation for the turkey rolls. No significant differences were found between heat treatments, holding time, or chill state (done at Iowa only). Overall, thiamin values were lowest in the Iowa study. This finding may be attributed to the fact that the roasts were covered during cookina. Thus thiamin, which is water soluble, could have been lost in the drippings. Moisture content of cooked roasts ranqed between 66.7 and $70.3 \%$. Fat content in turkey roasts at Illinois averaged $1.86 \%$, and at Kansas $5.02 \%$.

Statistical analysis was completed on combined values for 111 inois and Kansas, because the same preparation procedures and analytical methods were used. Comparison of thiamin values obtained for a check sample (Gerber strained pork) agreed closely. The coefficient of variation for thiamin values for the two states was 7.80 , which indicated good reproducibility of the data between and within laboratories. Differences observed in thiamin 
content in turkey roasts analyzed in the two Agricultural Experiment Stations could be attributed to variability in raw material. When thiamin values obtained at Kansas and Illinois were adjusted for moisture and fat content of the turkey meat and expressed on the moisture and fat-free basis, differences (134-209 mcq/100q) were not statistically significant.

Implications

The practices of pre-cooking meats and holding, either hot or chilled, are common in the foodservice industry. Nutrient content, as measured by losses of the indicator vitamin thiamin, decreased during the holdina period. Earlier studies reported that the destruction of thiamin ranged between 25 and $40 \%$ during cooking of turkey or chicken, depending on end-Doint temperature and cooking temperature (19-21).

The NC-120 study was designed to determine if convection heating of turkey rolls by either home or foodservice techniques resulted in similar values for thiamin retention. Results showed that differences were small and not of practical importance. Chilling meat and then reheating did not have a detrimental effect on thiamin retention. Differences in procedures (e.q. covered vs. uncovered pans, oven loads) between home and foodservice operations could account, in part, for variability in the values observed.

Low temperature cooking $\left(105^{\circ} \mathrm{C}\right)$ is another foodservice practice that is believed to result in higher yield and better sensory and, perhaps, nutritional characteristics. In this collaborative study, thiamin content and retention were similar in all cooking and holding procedures. Thus it appears that using recommended times, temperatures, and procedures for microbioloqically safe and sensorially acceptable turkey roasts results in satisfactory nutritional quality. 
MICROBIOLOGICAL SAFETY

Raw Product

Total aerobic plate counts on surfaces of turkey rolls ranqed from 10,000 to $560,000 / g$ as shown in log format in Tables 10 and 11 . There was good agreement in results from the three Agriculture Experiment Stations (Minnesota, Nebraska, and Wisconsin) although there were minor differences in methodology. Observations were made by Minnesota and Nebraska on the internal section of the rolls. The magnitude and range of internal counts were similar to those observed for the surface counts (Table 10), thereby indicating the same extent of contamination throughout the rolls. This microbial load was below that commonly accepted by state requlatory agencies (22).

Coliform counts on surface samples were hiqhly variable and ranaed from below the level of detection to $4,800 / 9$ as shown in Tables 10 and 11 . The inner portion of the rolls contained similar numbers of coliform contamination as those observed on the surfaces (Table 10).

Cooked Product

Roasting the turkey rolls at $135^{\circ} \mathrm{C}$ (Minnesota and Nebraska) to an internal temperature of 77 to $82^{\circ} \mathrm{C}$ reduced the total aerobic plate count to $300 / \mathrm{g}$ or less. These results were in harmony with previous observations using a similar quantity of meatloaf (23). No coliform organisms were detected in cooked turkey at Minnesota and Nebraska. The lowest total aerobic count in roasted turkey after hot-holding (Wisconsin) was below the detectable level by commonly used methods and the highest count was approximately 300/a (Table 12). Thus, it was apparent that a major portion of the contaminating microflora was extremely heat sensitive. Although total aerobic plate count increased in these trials during hot-holding, this increase could be attributed to sampling error, recontamination, or laboratory error. 
TABLE 10. Microbial Evaluation of Surface and Core Samples of Raw Turkey Rolls at Minnesota and Nebraska.

\begin{tabular}{|c|c|c|c|c|}
\hline \multicolumn{5}{|c|}{ Log of Total Aerobic Plate Count } \\
\hline \multicolumn{3}{|c|}{ Surface Samples } & \multicolumn{2}{|c|}{ Core Samples } \\
\hline $\begin{array}{c}\text { Trial } \\
1 \\
2 \\
3 \\
4\end{array}$ & $\begin{array}{c}\text { Minnesota } \\
4.48 \\
4.66 \\
4.97 \\
5.48\end{array}$ & $\begin{array}{c}\text { Nebraska } \\
4.00 \\
4.98 \\
4.61 \\
4.81\end{array}$ & $\begin{array}{c}\text { Minnesota } \\
4.34 \\
5.38 \\
5.04 \\
5.91\end{array}$ & $\begin{array}{c}\text { Nebraska } \\
3.78 \\
3.60 \\
4.69 \\
4.48\end{array}$ \\
\hline Average & 4.90 & 4.36 & 5.17 & 4.14 \\
\hline \multicolumn{5}{|c|}{ Log of Coliform Count } \\
\hline \multicolumn{3}{|c|}{ Surface Samples } & \multicolumn{2}{|c|}{ Core Samples } \\
\hline $\begin{array}{c}\text { Trial } \\
1 \\
2 \\
3 \\
4\end{array}$ & $\begin{array}{c}\text { Minnesota } \\
2.20 \\
3.04 \\
2.70 \\
3.34\end{array}$ & $\begin{array}{l}\text { Nebraska } \\
\quad<1 \\
<1 \\
<1 \\
<1\end{array}$ & $\begin{array}{c}\text { Minnesota } \\
1.90 \\
2.60 \\
1.85 \\
2.76\end{array}$ & $\begin{array}{l}\text { Nebraska } \\
<1 \\
<1 \\
<1 \\
<1\end{array}$ \\
\hline Average* & 2.82 & रा & 2.28 & $\overline{r T}$ \\
\hline
\end{tabular}

TABLE 11. Microbial Evaluation of Surface Samples of Raw Turkey Rolls at Wisconsin.

\begin{tabular}{ccc}
\hline Trial & Log Total Count & Loq Coliform Count \\
1 & 4.72 & $<1$ \\
2 & 5.28 & 3.45 \\
3 & 5.40 & 3.06 \\
4 & 4.71 & 2.26 \\
5 & 5.70 & 2.46 \\
6 & 5.75 & 3.68 \\
7 & 4.73 & 3.33 \\
8 & 5.11 & $<1$ \\
9 & 5.26 & 3.23 \\
10 & 5.41 & NAa \\
Averageb & & 2.61 \\
\hline
\end{tabular}

$a_{N A}=$ not available.

bAverage values used $<1$ as 1 . 
TABLE 12. The Effect of Cooking to $77^{\circ} \mathrm{C}$ and Subsequent Hot-Holding on the Total Microflora of Turkey Roasts at Wisconsin.

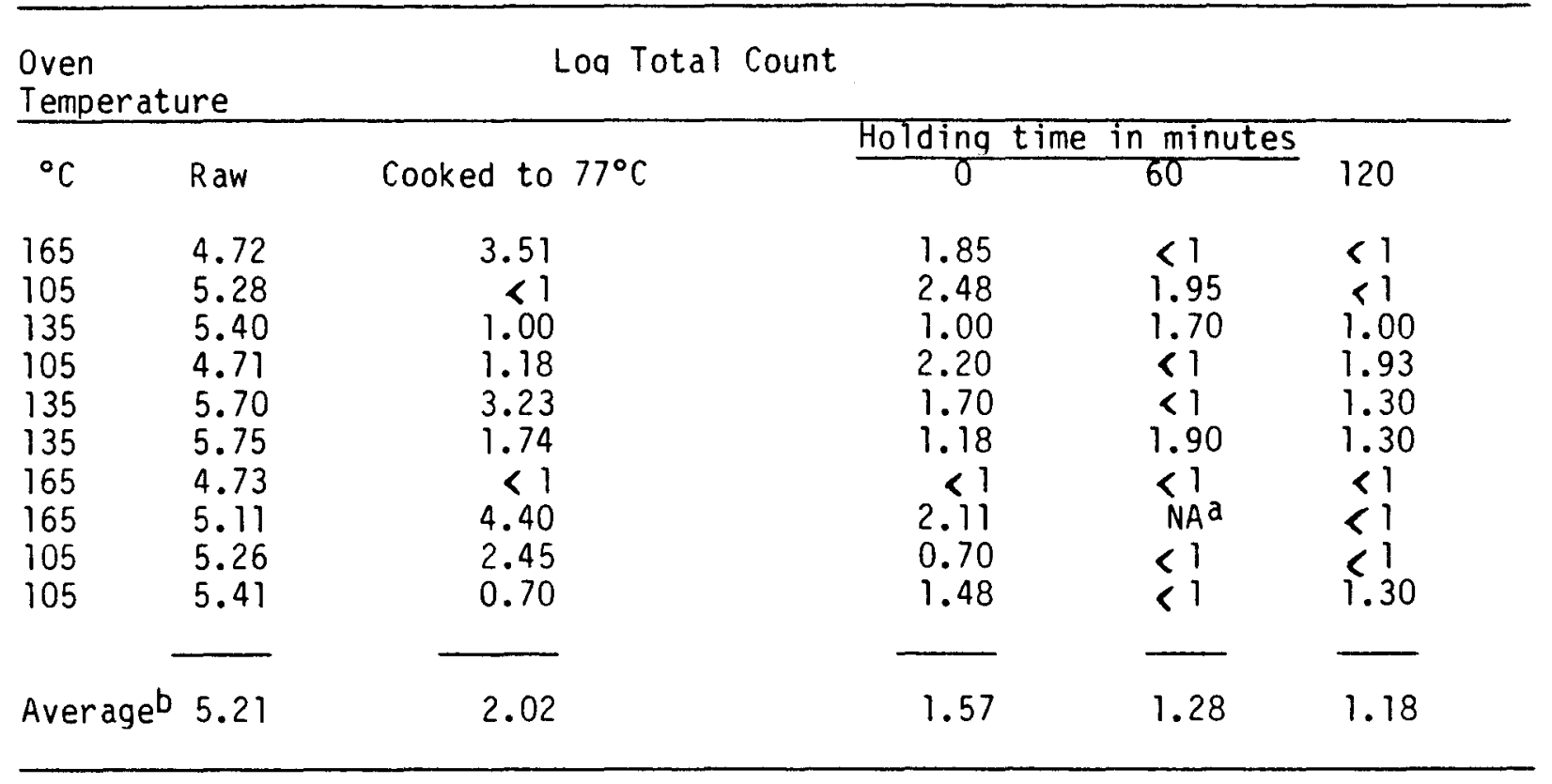

anA = not available.

bAverage values used $<1$ as 1 .

Complete elimination of the coliforms was attained by roasting to a temperature as low as $77^{\circ} \mathrm{C}$ at the geometric center of a turkey roast. These data support the observation of extreme heat sensitivity of the contaminating microflora.

\section{CHEMICAL SAFETY}

Results of the polychlorinated biphenyl (PCB) analyses for turkey rolls obtained from four Agricultural Experiment Stations that had received product from the common lot of turkey rolls supplied by this contract, established that these turkey rolls had nondetectable levels of PCBS. Fiqure 3 compares the GLC/integrator curve of one of the turkey roll samples analyzed from product obtained from Kansas with that of an Aroclor 1254 standard. 
Although PCB spill accidents have resulted in feed contamination and subsequent poultry contamination in localized areas, the general levels of PCBs in meat, fish, and poultry have declined. Thus, although it is not surprising, it is reassuring to find nondetectable levels of PCBs in these turkey rolls.

The U.S. Food and Drug Administration (FDA) conducts Total Dietary Studies to determine the dietary intake of pesticides, industrial chemicals, heavy metal, and radionuclides. These studies involve retail purchases throuqhout the year of 12 food groups for adult diets from selected cities in five districts. The latest published data qave the results of analyses in 1980-82 (24). Two of the meat, fish and poultry groups had detectable levels of PCBs with the range in concentration of these positive samples reported as beina a trace. For both 1978-79 and 1979-80, two of the 20 meat composites were positive and the averaqe level reported was a trace (25-26). For the 1977-78 sample data, five composites of meat, fish and poultry from the 20 cities monitored showed positive PCB results (27). One of the composites had 0.05 ppm, while four had trace levels. Thus, the general levels of PCB residue in meat, fish, and poultry in representative retail markets have declined to trace or nondetectable levels.

\section{ENERGY USE}

Analysis of variance procedures for the data qiven in Table 13, when two turkey rolls were heat processed, revealed that increasing the oven temperature did not significantly increase the total processing losses. Product yields for the turkey roasts ranqed from 76 to $82 \%$. 
TABLE 13. Heat Processing Parameters and Energy Consumption for Turkey Roasts at Iowa and Missouri.a

Oven Temperature $\left({ }^{\circ} \mathrm{C}\right)$

\begin{tabular}{|c|c|c|c|c|c|}
\hline \multicolumn{2}{|c|}{105} & \multicolumn{2}{|c|}{135} & \multicolumn{2}{|c|}{165} \\
\hline Mean & S.E. & Mean & S.E. & Mean & S.E. \\
\hline $9932^{X^{b}}$ & 39 & $10028^{Y}$ & 17 & $9973^{X Y}$ & 19 \\
\hline 8167 & 266 & 7748 & 227 & 7565 & 256 \\
\hline 17.79 & 2.47 & 22.75 & 2.16 & 24.13 & 2.61 \\
\hline 82.21 & 2.47 & 77.25 & 2.16 & 75.86 & 2.61 \\
\hline
\end{tabular}

Heat processing time:

\begin{tabular}{|c|c|c|c|c|c|c|}
\hline (min/load) & $263^{x}$ & 5.5 & $189^{Y}$ & 5.8 & $163^{2}$ & 1.9 \\
\hline$(\min / \mathrm{kg})$ & $26.42^{X}$ & 0.45 & $18.86^{Y}$ & 0.55 & $16.32^{2}$ & 0.19 \\
\hline
\end{tabular}

Energy usaqe:

$\begin{array}{llllrr}\text { (Wh/load) } & 5406^{X} & 397 & 6077^{X Y} & 271 & 6509^{Y} \\ (\text { Wh/kg) } & 545^{X} & 41 & 606^{X Y} & 296 & 28 \\ \end{array}$

aTwo turkey rolls were heat processed, uncovered in separate pans, at one time. Roasts were removed from the oven when both internal temperatures had reached $77^{\circ} \mathrm{C}$.

$N=6$; except for $165^{\circ} \mathrm{C}$ where $N=5$.

bMeans followed by the same letter within a row were not significantly different $(P<0.05)$. 
Because of the various weights of the raw turkey rolls, the mean initial weight for the turkey rolls processed at $105^{\circ} \mathrm{C}$ was lower than for those processed at $135^{\circ} \mathrm{C}$. When the heat processing times were expressed on both a load ( $\mathrm{min} / \mathrm{load})$ and weight $(\mathrm{min} / \mathrm{kg})$ basis, significant differences ( $P<0.05)$ were found among the three oven temperatures. The hiqhest oven temperature required less time than the two lower temperatures.

Eneray consumption did not follow this trend. On both an eneray usage per load (Wh/load) and weight $(\mathrm{Wh} / \mathrm{kg})$ basis, the highest oven temperature required more energy than the lowest one. However, no significant differences were revealed between oven temperatures of 105 and $135^{\circ} \mathrm{C}$, and between 135 and $165^{\circ} \mathrm{C}$.

Thus, when only two turkey rolls are required, foodservice administrators have the assurance that food product yield will not be significantly lowered by choosing any of these three conditions with the Lange Model (ECCO-6) of forced-air convection oven. If $165^{\circ} \mathrm{C}$ is chosen, processing time is reduced and energy consumption is increased. If $135^{\circ} \mathrm{C}$ is used, eneray consumption is not significantly reduced, but processing time is significantly reduced. Choosing the last option $\left(105^{\circ} \mathrm{C}\right)$ significantly $(P<0.05)$ increases the required heat processing time, but does not significantly reduce enerqy consumption, compared to the $135^{\circ} \mathrm{C}$ temperature. Clearly, variables other than heat processing time and energy usaqe should be included in the decision making process.

An analysis of variance revealed sianificant differences amona the heat processing parameters for turkey rolls (Table 4). Data in Table 14 include findings when three different oven loads of turkey rolls were heat processed at an oven temperature of $135^{\circ} \mathrm{C}$. Energy usage (Table 14) was significantly greater on an oven load basis when 6 rolls were heat processed simultaneously, versus either 2 or 4 rolls. When energy usage was analyzed on a weight basis 
TABLE 14. Enerqy Usage for Heat Processing Three Oven Load Sizes of Turkey Roasts.

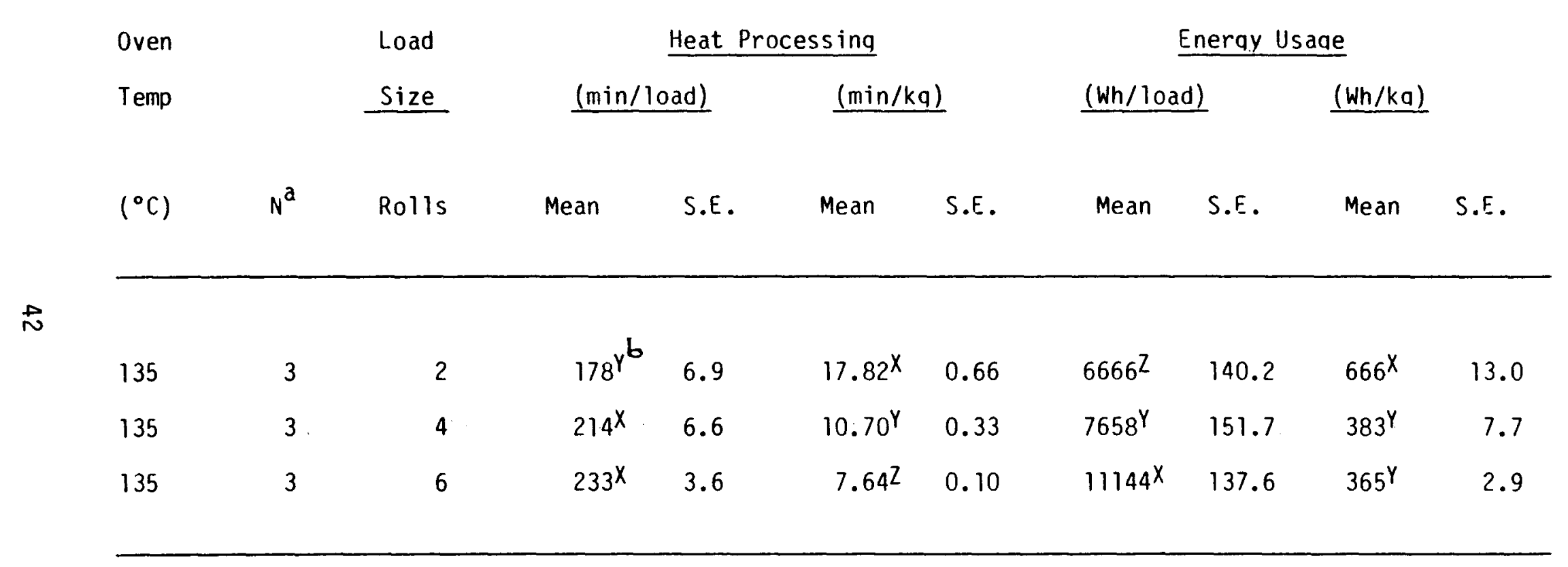

NOTE: Combined data from lowa and Missouri.

aRefers to the number of replications.

bMeans followed by the same letter within a column were not sianificantly different $(P<0.05)$. 
(wathours per kilogram of raw turkey roll), significantly $(P<0.05)$ greater amounts of energy were consumed for the oven load with 2 rolls.

Information in Table 14 represents an interesting finding for the foodservice manager. When either 4 or 6 turkey rolls were heat processed, no significant difference in heat processing times for an oven load was revealed. Furthermore, no significant difference in energy consumption per kilogram of raw turkey rolls was revealed at these oven loads. Therefore, when 6 turkey rolls are required, eneray $i$ conserved by heat processing them together, instead of having one oven load with 2 rolls and another with 4 rolls. Information shown in Table 14 revealed that the latter option required 14.3 kilowatt hours of enerqy, or $22 \%$ more energy than if all 6 rolls were processed together in one oven.

Energy data from wisconsin are qiven in Table 15 for each of the nine treatments studied. When compared to energy data for the ovens used at Iowa and Missouri, these data were considerably hiqher. The kilowatt rating for the Lanq convection oven is $10.8 \mathrm{~kW}$; for the Blodqett (used at Wisconsin), $11.0 \mathrm{~kW}$. Direct comparisons between the two models of forced-air convection ovens can not be made because both models have different efficiencies. For example, at $105^{\circ} \mathrm{C}$ with two turkey rolls, the Lang model operated at $11 \%$ of the heat processina time; the Blodgett, 24\% (Tables 13 and 15). The latter model is an older one with different insulation and thermostat controls and had greater heat losses via the cavity walls, doors and vents.

Several trends are apparent from the data qiven in Table 15. As the load size increased for each of the three oven temperatures, the per unit heat processing time $(\mathrm{min} / \mathrm{kg})$ and energy usage $(\mathrm{Wh} / \mathrm{kq})$ decreased. The heat processing time decreased as the oven temperature increased as expressed on an oven load basis. However, heat processing time for loads of 4 and 6 rolls was similar for the three 
TABLE 15. Energy Usage for Heat Processing Turkey Roasts at Wisconsin.

\begin{tabular}{|c|c|c|c|c|c|}
\hline $\begin{array}{l}\text { Oven } \\
\text { Temp } \\
\left({ }^{\circ} \mathrm{C}\right)\end{array}$ & $\begin{array}{c}\text { Load } \\
\text { size } \\
\text { (No Rolls) }\end{array}$ & $\frac{\text { Heat }}{(\min / \text { load })}$ & $\frac{\text { Processing }}{(\min / \mathrm{kg})^{*}}$ & (Wh/load) & $\frac{\text { Usaqe }}{(\mathrm{Wh} / \mathrm{kg})^{t}}$ \\
\hline \multirow[t]{3}{*}{105} & 2 & 267 & 26.86 & 10713 & 1078 \\
\hline & 4 & 288 & 14.29 & 13430 & 666 \\
\hline & 6 & 289 & 9.81 & 14946 & 507 \\
\hline \multirow[t]{3}{*}{135} & 2 & 199 & 20.20 & 11316 & 1149 \\
\hline & 4 & 216 & 11.09 & 14234 & 731 \\
\hline & 6 & 211 & 7.13 & 16947 & 572 \\
\hline \multirow[t]{3}{*}{165} & 2 & 162 & 16.62 & 11651 & 1196 \\
\hline & 4 & 186.5 & 9.49 & 15100 & 769 \\
\hline & 6 & 193 & 6.57 & 18714 & 637 \\
\hline
\end{tabular}

NOTE: A three by three factorial design (three oven temperatures $x$ three oven load sizes) was used to monitor energy consumption and time for heat processing in a convection oven.

Only one trial was conducted for each treatment; thus, nine trials were conducted.

Additionally, one experiment with load size of 2 rolls at oven temperature of $105^{\circ} \mathrm{C}$ was repeated to assess consistency of the experiments.

* Min/kg and Wh/kg was based on weight of raw turkey meat. 
oven temperatures. As anticipated, total energy consumption increased as the size of the oven load increased from two to six turkey rolls.

Information given in Table 15 for the oven temperature of $135^{\circ} \mathrm{C}$ follows similar trends to the significant $(P<0.05)$ findings revealed at Iowa and Missouri (Table 14). In addition, similar trends are revealed when only two turkey rolls were heat processed (Table 13): (a) heat processing time decreased as oven temperature increased, and (b) energy usage (Wh/load) and (Wh/kg) increased as oven temperature increased. If foodservice managers are concerned about enerqy usage, oven load size of 6 rolls heated at $105^{\circ} \mathrm{C}$ will save $11 \%$ and $20 \%$ enerqy (Wh/kq), compared to rolls heated at 135 and $165^{\circ} \mathrm{C}$ (Table 15). However, oven load size of 6 rolls heated at $165^{\circ} \mathrm{C}$ will save $33 \%$ and $8 \%$ cooking time (min/kg), compared to rolls heated at $105^{\circ} \mathrm{C}$ and $135^{\circ} \mathrm{C}(\mathrm{Table} 15)$. Although oven load size of 6 rolls heated at $135^{\circ} \mathrm{C}$ took more time (8\%) than those heated at $165^{\circ} \mathrm{C}$, the oven load size of 6 rolls heated at $135^{\circ} \mathrm{C}$. saved more enerqy (10\%) than those heated at $165^{\circ} \mathrm{C}$. Therefore, oven load size of 6 rolls heated at $135^{\circ} \mathrm{C}$ or $165^{\circ} \mathrm{C}$ would be recommended if both heating time and enerqy use are of concern.

Foodservice managers need to recognize that although the largest oven load can save more energy during heat processing, the storaqe and reheating of leftovers could require additional eneray consumption. Enerqy usage of three hot-holding loads (4,8, or 12 pans) was not sianificantly different after one and two hours of hot-holding in the cabinet at wisconsin. Hence, the size of the loads did not affect the eneray consumption during hot-holdina. At Iowa, reheating time and the amount of enerqy to reheat turkey slices to $66^{\circ} \mathrm{C}$ and to hold at that temperature for up to $2 \mathrm{hr}$ were not significantly different for slices originally cooked at different temperatures. 


\section{CONCLUSIONS AND RECOMMENDATIONS}

The following conclusions and recommendations are supported by the results of this project.

1. Sensory quality can be maintained while minimizing last minute preparation time by using low temperatures and long roasting times for roastina turkey rolls. However, should other procedures (short, high temperature roasting; roasting, chilling, and reheating) fit scheduling, personnel management, equipment availability, and eneray savinq reauirements, sensory quality is not affected as adversely as is believed qenerally.

2. Nutrient content of turkey rolls, as measured by losses of the indicatorvitamin thiamin, was decreased sliahtly by heat processing. However, the losses of the labile vitamin were small and probably not of practical importance. Using recommended times, temperatures and procedures for preparing acceptable turkey roasts results in satisfactory nutritional quality.

3. The variable counts of both total and coliform orqanisms constitute potential for spoilage if turkey rolls are mishandled in the either raw or cooked state. Roasting to an internal temperature of $77^{\circ} \mathrm{C}$ destroyed coliforms and reduced the total aerobic count, however, some residual orqanisms of no public hazard remained. 
4. This lot of commercial turkey rolls did not contain detectable levels of PCBS. Continued surveillance of the U.S. food supply, however, is necessary to ensure that environmental translocations and/or accidental spills do not cause food contamination with these types of industrial chemicals.

5. Based upon the experiments with two models of convection ovens, when two turkey rolls are required, an oven temperature of $135^{\circ} \mathrm{C}$ would be recommended. This option consumed less eneray on a watthour per kilogram of product weight basis. When either four or six rolls are required, oven temperatures of either $135^{\circ} \mathrm{C}$ or $165^{\circ} \mathrm{C}$ consume similar levels of eneray, when analyzed on a product weight basis.

This document reports research undertaken in cooperation with the US Army Natick Research, Development and Engineering Center under Contract No. DAAK60-84-C-0089 and has been assigned No. NATICK/TR-87/-26 in the series of reports approved for publication. 

REFERENCES:

1. Anonymous, "1986 Annual Report. The Market." Restaurants \& Institutions, Vol. 96, pp. 117-24, January 1986.

2. Linstrom, H.R. and Putnam J.J., "Buildina a Foodservice Database." National Food Review, United States Department of Aariculture, National Economics Division, Economic Research Service, pp. 22-23, Winter 1986.

3. Anonymous, The Restaurant Industry in 1990, National Restaurant Association, Current Issues Report, Washinaton, D.C., not dated.

4. Anonymous, Food Consumption: Prices and Expenditures, 1964-84. Statistical Bulletin No. 736, Economic Research Service, United States Department of Agriculture, Government Printing Office, Washinqton, D.C., 1985.

5. Auqustin, J., Klein, B.P., Becker, D. and Venuqopal, P.B., editors, Methods of Vitamin Assay, 4th Edition, John Wiley \& Sons, New York, NY, 1985.

6. Horowitz, W., editor, Official Methods of Analysis, 13th Edition, Association of Official Analytical Chemists, Washington, D.C., 1980.

7. Speck, M.L., editor, Compendium of Methods for the Microbioloaical Examination of Foods, 2nd Edition, American Public Health Association, Washington, D.C., 1984.

8. Yadrick, M.K., Funk, K. and Zabik, M.E. "Dieldrin Residues in Bacon Cooked by Two Methods." Journal of Aqricultural and Food Chemistry, Vol. 19, pp. 491-99, May-June 1971.

9. Unk lesbay, N., Unk lesbay, K., Buerqler, D. and Ellersieck, M., "Eneray Usage for Convective Heat Processing of Sausage Patties." School Food Service Research Review, Vol. 6, No. 1, pp. 14-19, Winter 1982 .

10. Unk lesbay, N., Heyne, L. and Ellersieck, M., "Students Study Enerqy Usaqe for Heat Processing Pizzas." Hospitality Education Research Journal Vol. 8, No. 2, pp. 1-14, May 1984.

11. Harrington, G. and Pearson, A.M., "Chew Count as a Measure of Tenderness of Pork Loins with Various Degrees of Marbling." Journal of Food Science, Vol. 27, pp. 106-10, January-December 1962.

12. Cover, S., Hostetler, R.L. and Ritchey, S.J. "Tenderness of Beef. IV. Relations of Shear Force and Fiber Extensibility to Juiciness and Six Components of Tenderness." Journal of Food Science, Vol. 27, pp. 527-36, January-December 1962.

13. Schultz, H.G., "Sources of Invalidity in the Sensory Evaluation of Foods." Food Technology, Vol. 25, No. 3, pD. 249-53, March 1971. 
14. O'Mahony, M., "Some Assumptions and Difficulties with Common Statistics for Sensory Analysis." Food Technology, Vol. 36, No. 11 pp. 75-82, November 1982.

15. Milliken, G.A. and Johnson, D.E., Analysis of Messy Data Vol 1: Desianed Experiments, Lifetime Learning Publications, Belmont, CA., 1984.

16. Syarief, H., Mamann, D.D., Giesbrecht, F.G., Youna, C.T., and Monroe, R.J. "Comparison of Mean and Consensus Scores from Flavor and Texture Profile Analyses of Selected Food Products." Journal of Food Science, Vol. 50, pp. 647-50, May-June 1985.

17. Watt, B.K. and Merrill, A.L. Composition of Foods. Raw, Processed, Prepared. Agriculture Handbook No. 8, Consumer and Food Economics Institute, Agricultural Research Service, United States Department of Agriculture, Washington, D.C., December 1963.

18. Posati, L.P., Composition of Foods. Poultry Products. Raw, Processed, Prepared. Agriculture Handbook No. 8-5, Science and Education Administration, United States Department of Aqriculture, Washington, D.C., August 1979.

19. Cook, B.B., Morgan, A.F. and Smith, M.B., "Thiamin, Riboflavin, and Niacin Content of Turkey Tissues as Affected by Storage and Cooking." Food Research, Vol. 14, pp. 449-58, November-December 1949.

20. West, L.C., Titus, M.C. and Van Duyne, F.0., "Effect of Freezer Storaqe and Variations in Preparation on Bacterial Count, Palatability and Thiamin Content of Ham Loaf, Italian Rice and Chicken." Food Technoloay, Vol. 13, pp. 323-27, June 1959 .

21. Bowers, J.A. and Fryer, B.A., "Thiamin and Riboflavin in Cooked and Frozen, Reheated Turkey." Journal of the American Dietetic Association, Vol. 60, pp. 399-401, May 1972 .

22. Wehr, M., "Attitudes and Policies of State Governments." Food Technology, Vol. 32, pp. 63-67, Jan. 1978.

23. Maxcy, R.B., "Fate of Post-Cooking Microbial Contaminants of Some Major Menu Items." Journal of Food Science, Vol. 41, pp. 375-78, March-April 1976.

24. Gartrel1, M.J., Craun, J.C., Podrebarac, O.S. and Gunderson, E.L., "Pesticides, Selected Elements and Other Chemicals in Adult Total Diet Samples, October 1980-March 1982." Association of Official Analytical Chemists Journal, Vol. 69 pp. 146-59, January-February, 1986.

25. Gartre11, M.J., Craun, J.C., Podrebarac, D.S. and Gunderson, E.L., "Pesticides, Selected Elements and Other Chemicals in Adult Total Diet Samples, October 1978-September 1979." Association of Official Analytical Chemists Journal, Vol. 68, pp. 862-75, September-October, 1985a. 
26. Gartre11, M.J., Craun, J.C., Podrebarac, D.S. and Gunderson, E.L., "Pesticides, Selected Elements and Other Chemicals in Adult Total Diet Samples, October 1979-September 1980." Association of Official Analytical Chemists Journal, Vol. 68, pp. 1184-97, November-December 1985b.

27. Podrebarac, D.S., "Pesticide, Metal and Other Chemical Residues in Adult Total Diet Samples. (XIV). October 1977-September 1978." Association of Official Analytical Chemists Journal, Vol. 67, pp. 176-85, January-February 1984. 

PAPERS

Brown, N.E. and Chyuan, J.Y.A. 1987. Convective heat processinq of turkey roll: Effects on sensory quality and enerqy usage. J. Amer. Dietet. Assoc. In press (lowa).

Cremer, M.L. 1986. Sensory quality of turkey rolls roasted and held in an institutional convection oven with and without chilled storage. J. Food Science. 51(4): 868-872. (Ohio)

DiGiorqio, A.M. and Setser, C.S. 1987. Sensory and nutritional quality of thermally processed turkey rolls for foodservice. School Food Service Research Review In press. (Kansas)

Hsieh, J. and Matthews, M.E. 1986. Energy use, time and product yield of turkey rolls at three oven loads and cooking temperatures in a convection oven. J. Foodservice Systems. 4(2):97-106 (Wisconsin).

Snyder, P.0. and Matthews, M.E. 1987. Quality of turkey roasts cooked and held hot. Catering \& Health: International Journal of Hyaiene and Nutrition in Catering (Foodservice). In press. (Wisconsin).

Snyder, P.0., Matthews, M.E. and Maxcy, R.B. 1987. Microbioloqical quality of $r$ aw and cooked turkey roasts under conditions simulating school food services. School Food Service Research Review. In press (Wisconsin and Nebraska).

Unk lesbay, N.F., Brown, N.E., and Matthews, M.E. 1987. Monitorina food temperatures during convective heating: Implications for research procedures. J. Food Science. In press. (Missouri, Iowa, Wisconsin).

Unk lesbay, N.F., Brown, N.E., and Matthews, M.E. 1987. Bentonite Models simulate energy usage for turkey rolls during convective heating. $\mathrm{J}$. Amer. Dietet. Assoc. Submitted. (Missouri, Iowa, Wisconsin).

ABSTRACTS

DiGiorgio, A. and Setser, C. 1986. Sensory and nutritional auality of thermally processed turkey roasts for foodservice. Poster Session presented at 46th Annual Meeting of Institute of Food Technologists. (Proaram Booklet p. 184) Dallas, TX June 15-18, 1986. (Kansas)

Perry, A.K. and Klein, B.P. 1986. Quality characteristics of turkey roasts cooked by convection heating. Poster Session presented at 46 th Annual Meeting of Institute of Food Technologists. (Program Booklet D 184). Dallas, TX June $15-18,1986$ (I1) inois).

Brown, N.E. and Chyuan, J.Y.A. 1986. Effect of cooking temperature, holdina treatment and holding time on sensory quality of turkey rolls. Poster session presented at 69th Annual Meeting of The American Dietetic Association. (Program Book let p. 56). LasVegas, NV October 27-31 (Iowa). 
5866. 